\title{
КАК ПРЕОДОЛЕТЬ ОТСТАВАНИЕ РОССИИ ПО ПРОДОЛЖИТЕЛЬНОСТИ ЖИЗНИ?
}

\author{
КРУГЛЫЙ СТОЛ ИНСТИТУТ ДЕМОГРАФИИ НИУ ВШЭ И РЕДАКЦИИ \\ ЖУРНАЛА «ДЕМОГРАФИЧЕСКОЕ ОБОЗРЕНИЕ»
}

\begin{abstract}
Материаль Круглого стола, организованного редакиией «Демографического обозрения» совместно с Институтом демографии НИУ ВШЭ. Участники Круглого стола констатируют значительное отставание России от большинства развитых стран по продолжительности жизни, обсуждают новейтие тенденияи смертности и продолжительности жизни в России и вопрос об их региональных различиях. Критической оченки заслужсивает, по их мнению, современное состояние информации о смертности и заболеваемости населения России. Обсуждаются также половозрастные особенности смертности и изменения в структуре причин смерти в России с 1990 2., рассматривается вопрос о связи тенденций смертности с потреблением алкоголя. Участники Круглого стола обращают внимание на низкую эффективность российской системы здравоохранения и высказывают свои соображения о путях совершенствования этой системы, без чего невозможно преодоление нынешнего российского отставания.
\end{abstract}

В Круглом столе, проходившем 17 апреля 2015 г., приняли участие ведущчие специиалисты в области демографии и охраны здоровья:

Е.М. Андреев, к.ф.-м.н., ведущий научный сотрудник Центра демографических исследования Российской экономической школь;

А.Г. Вишневский, д.э.н., директор Института демографии НИУ «Высшая школа экономики»;

С.П. Ермаков, профессор, д.э.н., главный научный сотрудник Института социиально-экономических проблем народонаселения РАН, главный научный сотрудник ЦНИИ организации и информатизации здравоохранения Минздрава РФ;

А.Е. Иванова, профессор, д.э.н., заведуюший Отделением статистики здоровья населения ЦНИИ организации и информатизации здравоохранения Минздрава РФ;

Е.А. Кваша, к.э.н., старший научный сотрудник Института демографии НИУ «Выстая школа экономики»;

Ю.М. Комаров, профессор, заслуженный деятель науки РФ, д.м.н., член Комитета гражданских инициатив;

Т.Л. Харькова, к.э.н., старший научный сотрудник Института демографии НИУ «Высшая школа экономики»;

С.В. Шишкин, д.э.н., директор Центра политики в сфере здравоохранения «Выстая школа экономики»;

В.М. Школьников, к.г.н., заведующий Лабораторией демографических данных Института демографических исследований общества Макса Планка (Германия).

Ключевые слова: продолжительность жизни, смертность, причины смерти, система здравоохранения, Россия

\section{ОТСТАВАНИЕ НЕДОПУСТИМО ВЕЛИКО}

Вишневский: - Уважаемые коллеги, для начала я покажу несколько слайдов. Я вообще-то не собирался этого делать, но потом решил, что нужна какая-то затравка, чтобы обсуждение пошло живее. Вопросов, как вы видели, мы подготовили много, а времени, как всегда, мало. Призываю всех стараться компактно формулировать свои ответы на эти многочисленные вопросы.

Начну с картинки, которая всем известна (рисунок 1). 


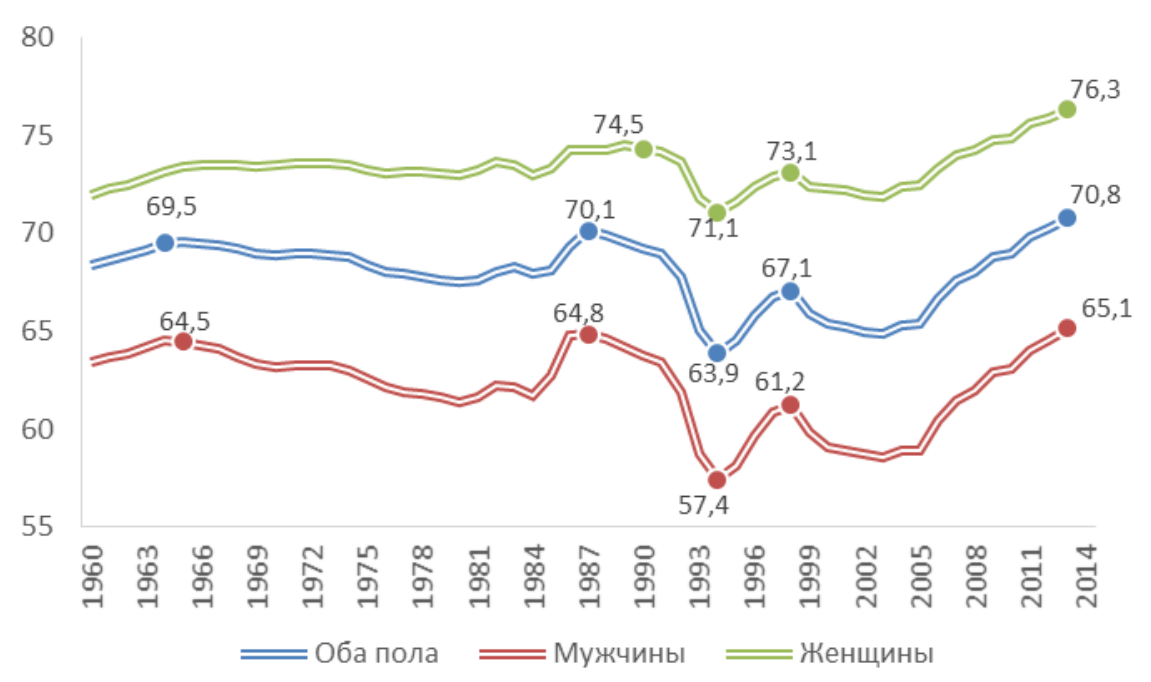

\section{Рисунок 1. Ожидаемая продолжительность жизни при рождении в России, 1960-2013, лет}

Мы уже привыкли к тому, что продолжительность жизни у нас постоянно колеблется то вверх, то вниз, не показывая, в общем-то, никаких принципиальных изменений. Сейчас мы впервые чуть-чуть превысили уровень, которого уже достигали в 1960-е и 1980-е годы. В 2009 г. впервые был превышен предыдущий максимум (1989 г.) для женщин, а в 2012 г. - максимум 1987 г. для обоих полов. В 2013 г. продолжительность жизни впервые превысила планку 65 лет и одновременно максимальный показатель 1987 г. для мужчин. Превышение есть, но пока оно настолько незначительно, что говорить о больших успехах преждевременно.

К тому же продолжительность жизни все еще растет, в основном за счет детских возрастов. Смертность взрослого населения, особенно мужского, остается высокой, продолжительность жизни мужчин в возрасте 15 лет, как видите, все еще ниже, чем в конце 1980-х и даже в середине 1960-х годов (рисунок 2).

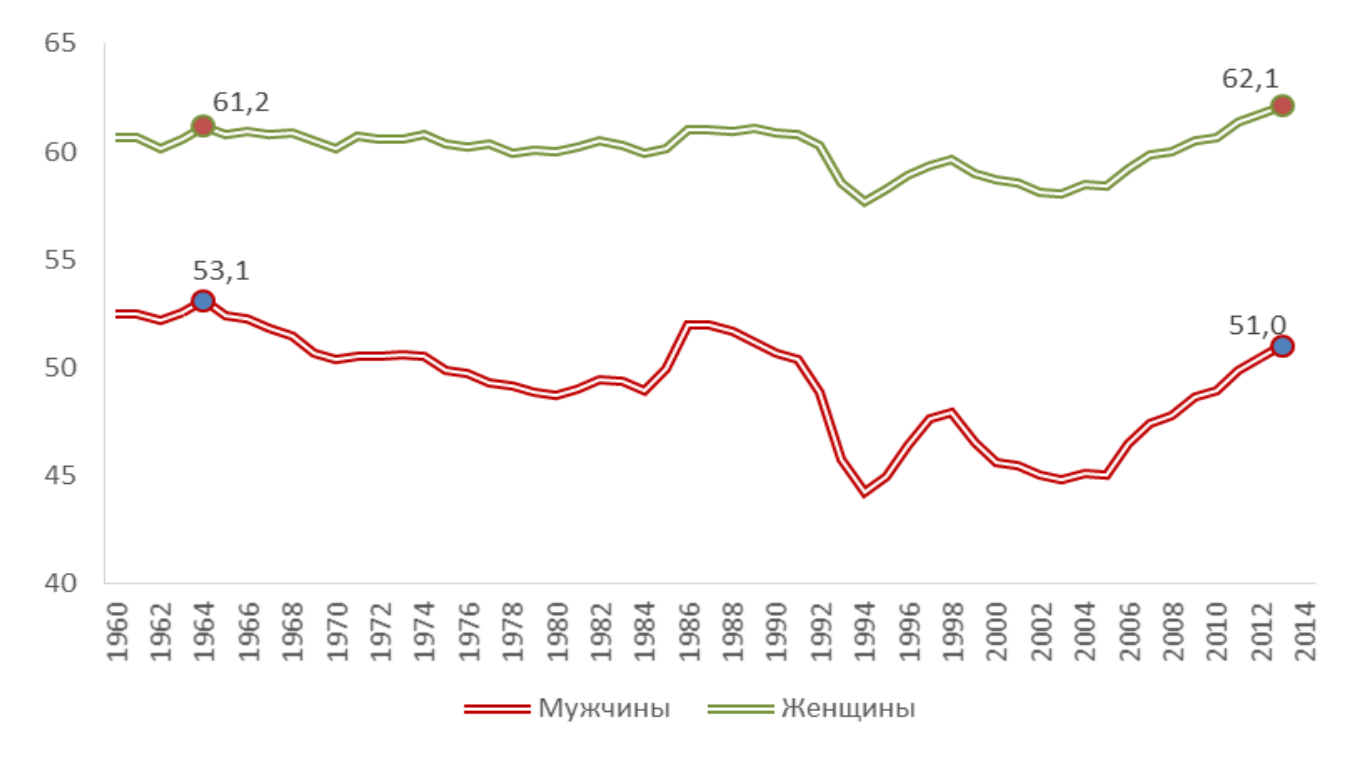

Рисунок 2. Ожидаемая продолжительность жизни в возрасте 15 лет в России, 1960-2013, лет 
В то время как в России на протяжении пяти-шести десятилетий продолжительность жизни то падая, то поднимаясь, топчется на месте, везде идет ее устойчивый рост, и наше отставание только нарастает. На следующем графике приведены данные по США, Японии, а также агрегированные данные для «старых» членов ЕС, входивших в него до расширения в мае 2004 г., - это все основные страны Западной Европы ${ }^{1}$ (рисунок 3).

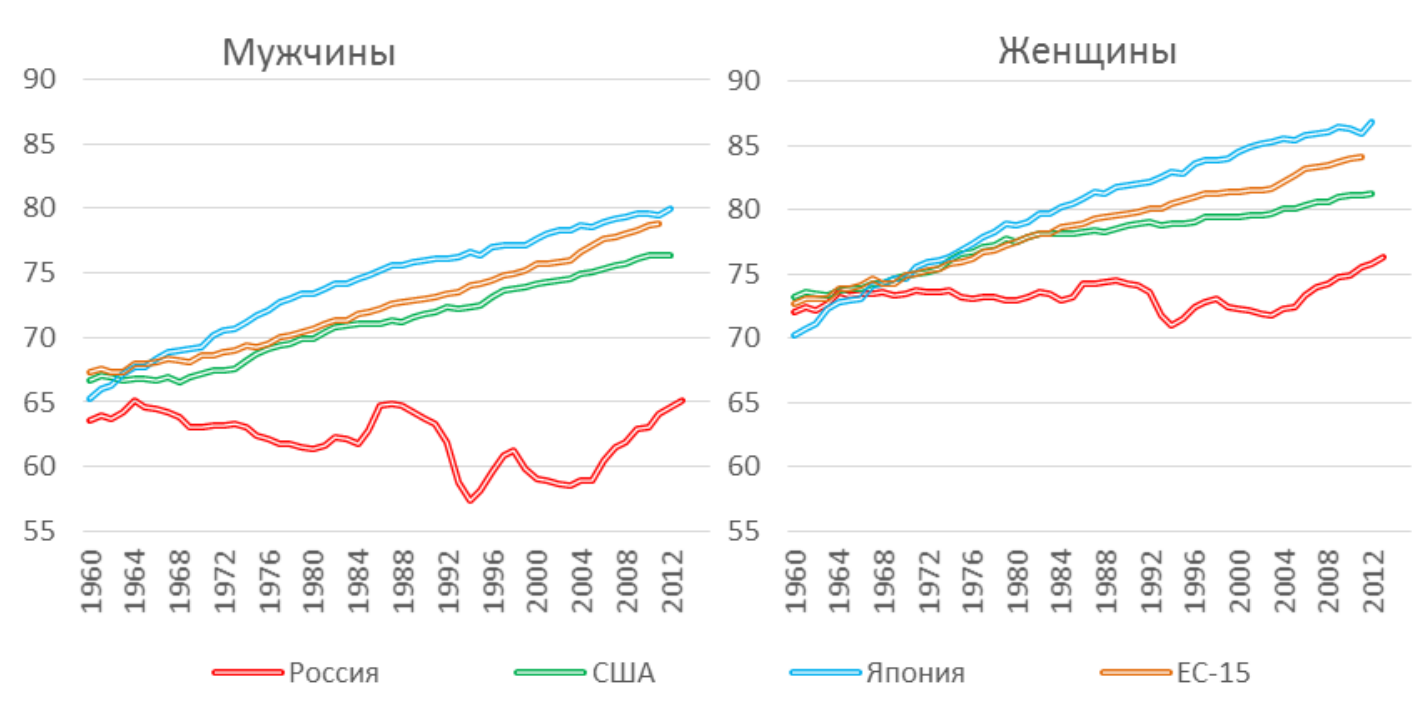

Рисунок 3. Ожидаемая продолжительность жизни при рождении в России, ЕС-15, США и Японии, 1960-2013, лет

Вы видите, что наше отставание, хотя и с некоторыми колебаниями, все время увеличивается, и сейчас, в общем-то, мы вернулись к тем масштабам отставания от опережающих нас стран (на 10-15 лет), какие отмечались только в начале XX века, когда, как известно, Россия была отсталой аграрной страной (рисунок 4).

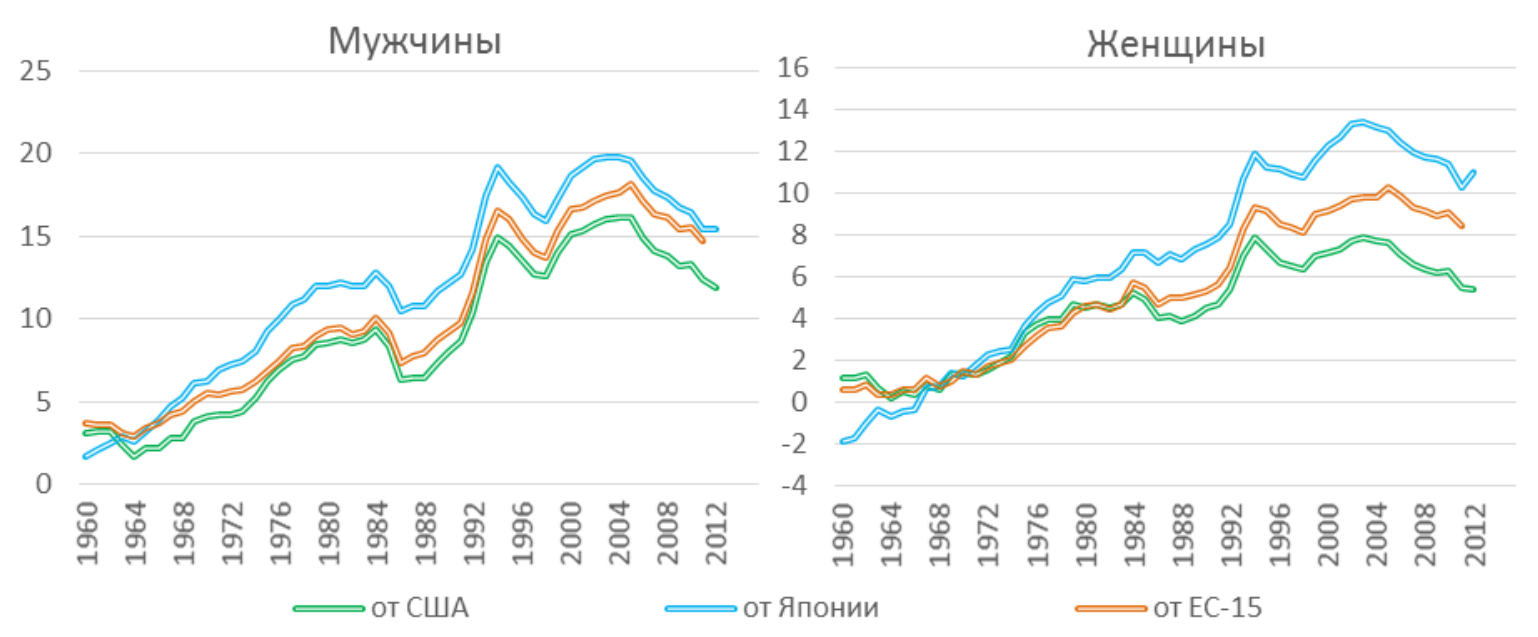

Рисунок 4. Отставание России по показателю ожидаемой продолжительность жизни при рождении от ЕС-15, США и Японии, 1960-2013, лет

\footnotetext{
${ }^{1}$ Австрия, Бельгия, Великобритания, Германия, Греция, Дания, Италия, Ирландия, Испания, Люксембург, Нидерланды, Португалия, Финляндия, Франция, Швеция.
} 
На что я хотел бы сейчас обратить внимание. В свое время американский гигиенист Милтон Террис (Milton Terris) ...

Комаров: - Он политолог, основатель и главный редактор журнала «Journal of Public Health Policy».

Вишневский: - Ну, может, он был и политологом, но больше все же гигиенистом. Он, кстати, приезжал в Советский Союз в свое время. Так вот он сформулировал, параллельно с Омраном, известным своей теорией эпидемиологического перехода, концепцию второй эпидемиологической революции. Как он писал в начале $70-$-х годов, «в ходе первой эпидемиологической революции, органы здравоохранения достигли чудес профилактики инфекционных заболеваний... То же самое может быть верно для второй эпидемиологической революции в профилактике неинфекционных заболеваний». Теперь, говорил он, здравоохранение подошло к «большой и трудной задаче: ни много ни мало, осуществить вторую эпидемиологическую революцию и спасти буквально миллионы мужчин и женщин от предотвратимых болезней, инвалидности и смерти» [Terris: 1156].

Так он формулировал новые задачи, и вот что из этого получилось - я снова сравниваю Россию с 15 западноевропейскими странами (рисунок 5).

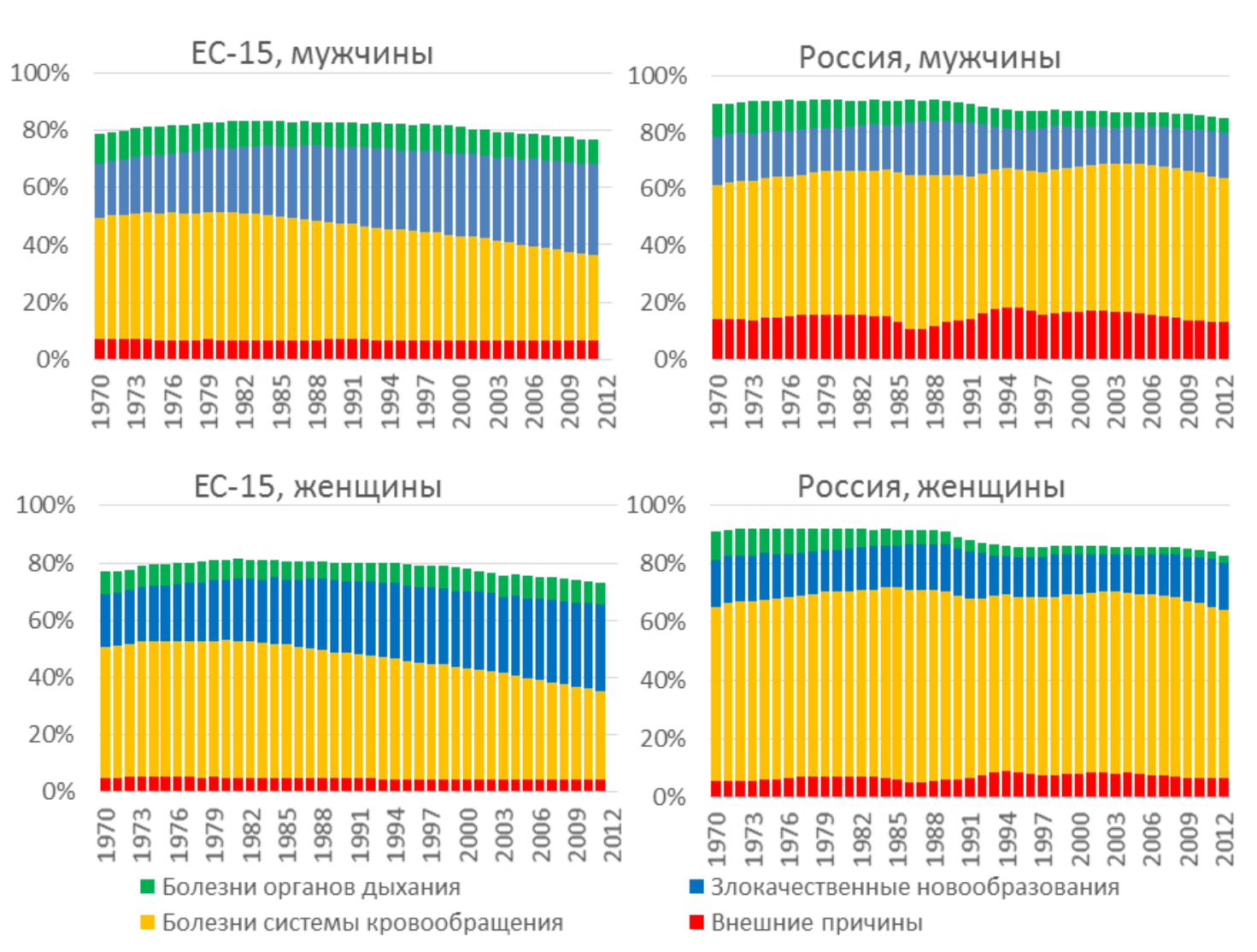

Рисунок 5. Совокупный вклад болезней системы кровообращения, новообразований, болезней органов дыхания и внешних причин в стандартизованный коэффициент смертности от всех причин в ЕС-15 и в России

Общую картину смертности в начале второй эпидемиологической революции Терриса определяли 4 класса причин смерти: сердечно-сосудистые заболевания, 
новообразования, внешние причины и болезни органов дыхания. На их долю приходилось порядка 80 или больше процентов, если говорить в терминах стандартизованного коэффициента смертности. Так было и в западных странах, и в России, в России - лишь ненамного больше.

Что происходило потом? Общий вклад четырех причин - и у них, и у нас - если и изменялся, то не существенно. Но если посмотреть на изменения внутренней структуры этого вклада, то разница сразу бросается в глаза. Особенно заметны различия в соотношении сердечно-сосудистых заболеваний и рака: на Западе эти соотношения очень заметно изменились, а в России - нет. Это тоже видно на рисунке 5.

A теперь посмотрим не структуру стандартизованного коэффициента, а его абсолютные значения - снова в сравнении с ЕС-15 (рисунок 6). Вы видите, что происходило у них и что происходило у нас.

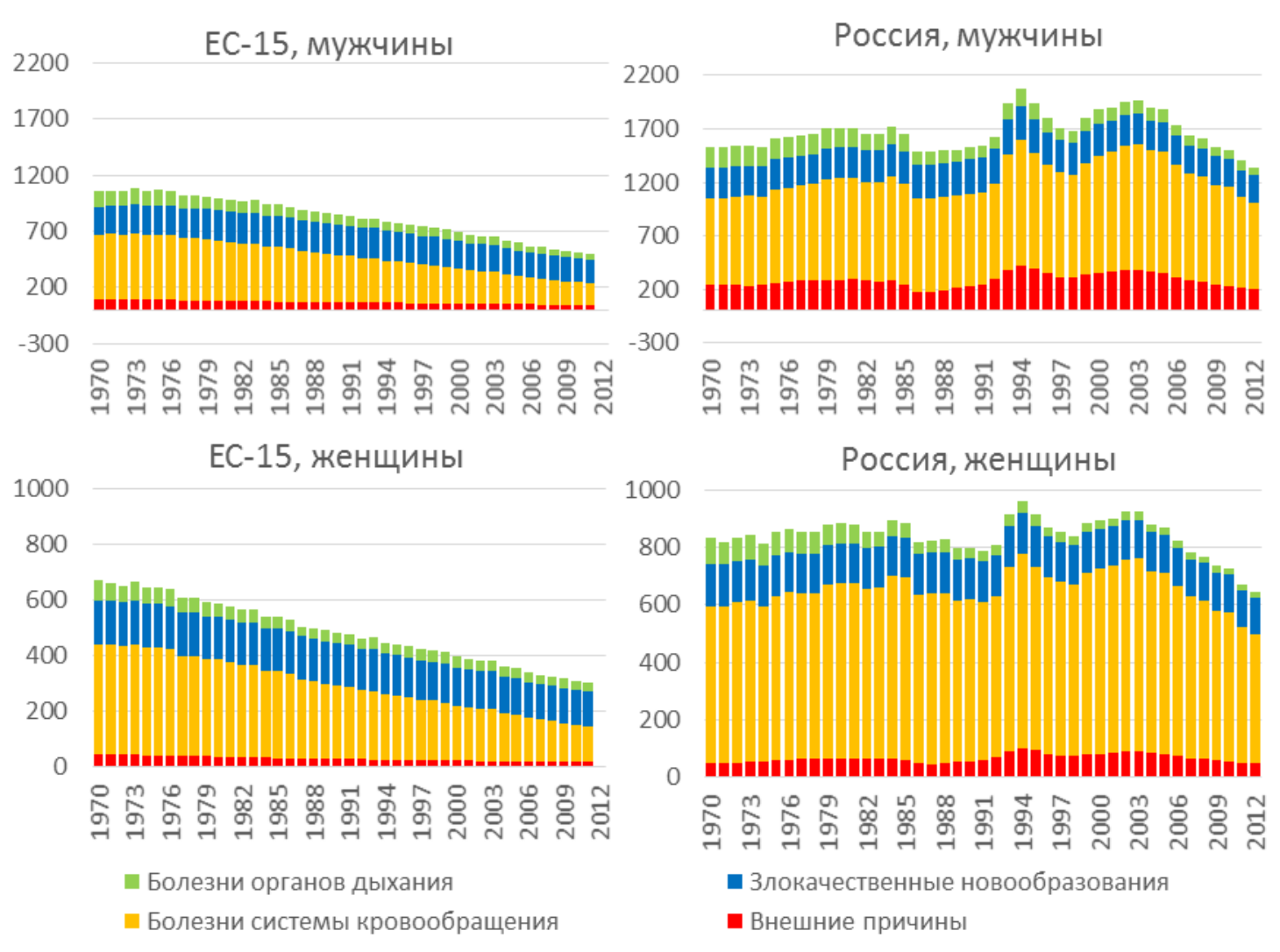

Рисунок 6. Стандартизованный коэффициент смертности от болезней системы кровообращения, злокачественных новообразований, болезней органов дыхания и внешних причин в ЕС-15 и в России, на 100000

Стандартизированный коэффициент у них резко снижался при изменении его внутренней структуры, у нас, как видите, ничего подобного не было: были колебания туда - сюда, но в общем на том же уровне, на каком мы были, примерно на таком и остались.

Очень важно также, что во всех развитых странах значительно увеличился средний возраст смерти от основных классов причин, ведь оттеснение смертности к старшим возрастам - это и есть ее снижение. И на следующем графике (рисунок 7) вы видите, что происходило у них и у нас. Россия - это красные столбики на графике. Они либо идут вверх 
- и тогда они очень низкие по сравнению со столбиками для других стран, либо даже идут вниз, чего для других стран не наблюдается. То есть там, где в других странах шел существенный рост среднего возраста смерти от всех основных причин, у нас либо рост был незначительным, либо даже вместо роста происходило снижение.

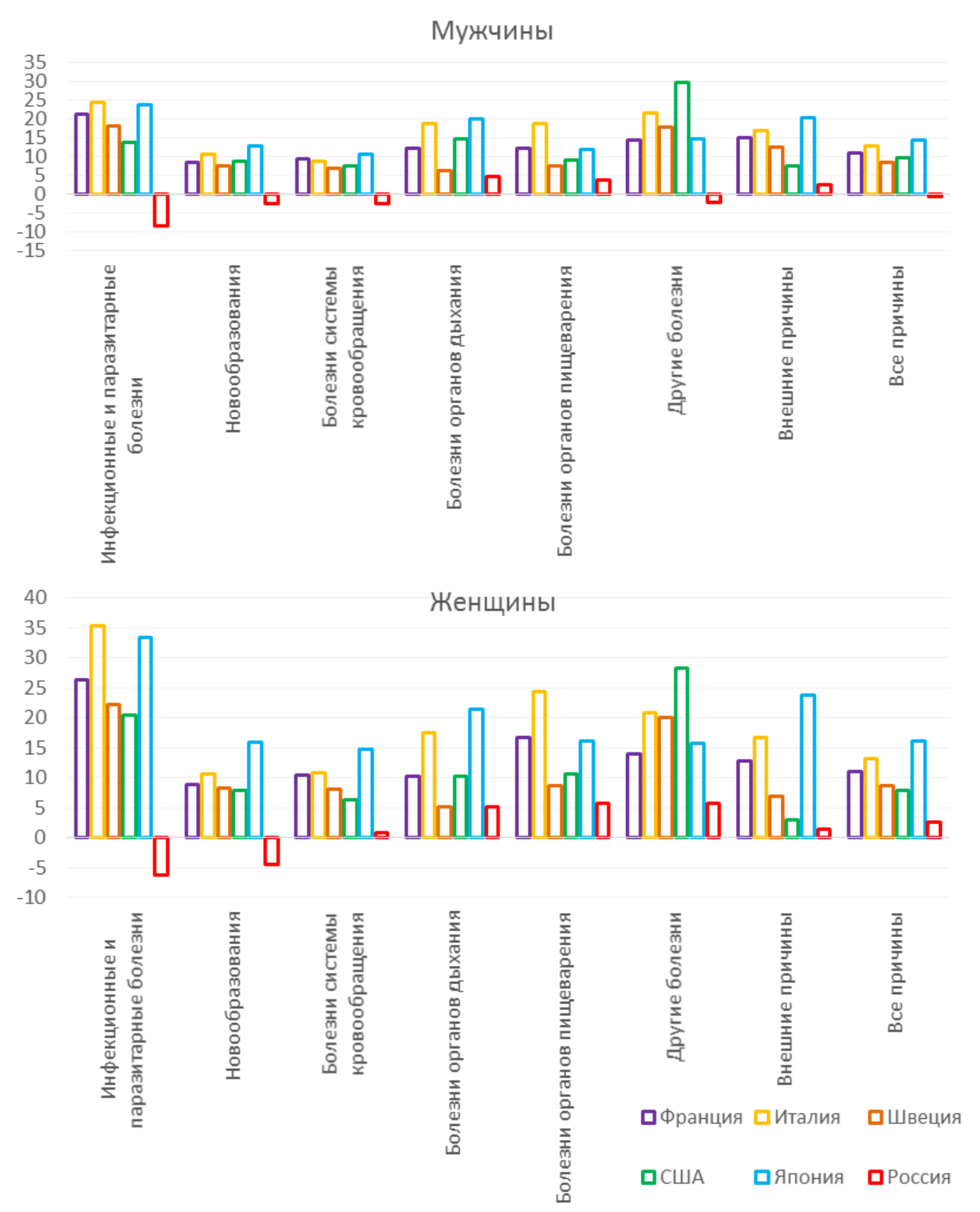

Рисунок 7. Изменение среднего возраста смерти от крупных классов причин 3950 лет в России, некоторых европейских странах, США и Японии, 1960-2010, лет

Похоже, что наше отличие от других стран не просто количественное, а качественное. Мы отставали и в 1960-е годы, но тогда отставание от европейских стран или США было сравнительно небольшим и понятным. С тех пор у них произошли очень большие изменения. Я бы сказал, что у них изменилась эпидемиологическая модель смертности: структура причин, от которых умирают люди, и возраст, в котором умирают в среднем от каждой крупной группы причин. Это, видимо, и была «вторая 
эпидемиологическая революция», о которой говорил Террис. А у нас никакой революции не было - мы, по сути, пропустили целый этап развития. Приведу маленькую табличку, показывающую, что за эти 50 лет произошло с ожидаемой продолжительностью жизни в России и в странах с низкой смертностью и каким огромным стало наше отставание (таблица 1).

Таблица 1. Изменение ожидаемой продолжительности жизни в России, странах ЕС-5, США и Японии и отставание России от указанных стран, 1960-2010, лет

\begin{tabular}{|c|c|c|c|c|}
\hline & Россия & EC-15 & США & Япония \\
\hline \multicolumn{5}{|c|}{ Изменение за 50 лет } \\
\hline Мужчины & $-0,50$ & 11,34 & 9,71 & 14,23 \\
\hline Женщины & 2,78 & 11,28 & 7,97 & 16,11 \\
\hline \multicolumn{5}{|c|}{ Отставание России в 2010 г. } \\
\hline Мужчины & & 15,56 & 13,28 & 16,46 \\
\hline Женщины & & 9,11 & 6,33 & 11,42 \\
\hline
\end{tabular}

Сейчас продолжительность жизни в России растет, но отставание остается очень большим. В чем его причины? Можем ли мы его преодолеть? Что для этого нужно сделать? Эти вопросы мы и хотели бы обсудить сегодня.

\section{ЧТО ПРОИСХОДИТ С ПРОДОЛЖИТЕЛЬНОСТЬЮ ЖИЗНИ В РОССИИ СЕЙЧАС: УСТОЙЧИВЫЙ РОСТ ИЛИ ОЧЕРЕДНОЕ КОЛЕБАНИЕ?}

Школьников: -Анатолий Григорьевич, в общем, вы правильную картину нарисовали. Можно говорить о том, что вначале у России было совсем небольшое отставание от наиболее развитых стран, потом оно увеличилось, а в 2000-е годы уменьшилось. Однако тут есть важные детали, которые нуждаются в дальнейшем изучении. Во-первых, природа отставания России в 1960-х или 1970-х годах была совсем не та, что, например, в 2000 г. Задействованы другие возраста и причины смерти. Ваши графики с декомпозицией продолжительности жизни по причинам смерти могут быть также неточными, потому что сейчас становится ясно, что у нас очень ненадежные регистрация, кодирование и диагностика причин смерти, особенно в старших возрастах. Диагностика в возрастах старше 80 лет, где регистрируется очень много смертей от сердечно-сосудистых заболеваний и рака, которые с переменным успехом конкурируют с так называемой «старостью», особенно неточна. Но знаем мы об этом пока очень мало. Россия - страна далеко не последняя в плане исследований в области смертности, но она и далеко не первая. У нас, конечно, не хватает доказательной базы и знаний по этим и другим важным деталям общей картины. Но сейчас я хочу отметить то, что мне кажется наиболее важным.

Я не согласен с вами в том, что касается смертности в России после 2003-2004 гг. На эту тему опубликовано пока две работы: одна - в журнале «Demographic Research» [McKee, Leon 2013: 917-950], другая - в «Population and Development Review» [Grigoriev et al. 2014: 107129]. Там показано, что в 2000-е годы был другой процесс по сравнению с тем, что происходило в 80-е и 90-е годы. Во-первых, длительность периода улучшений. Начиная с 1965 г. в истории России не было ни одного эпизода роста ожидаемой продолжительности жизни, который бы продолжался больше двух лет, за исключением антиалкогольной компании, во время которой рост продолжительности жизни наблюдался с 1985 по 1987 г. 
включительно. Последний период роста ожидаемой продолжительности жизни продолжается уже более 10 лет - с 2003 по 2014 гг. То есть уже длительность этого процесса говорит о том, что происходит нечто иное. Во-вторых, состав причин смерти, определяющих улучшение, другой. В наших статьях показано, что в 2000-е годы было впервые достигнуто снижение смертности в старших возрастах от сердечно-сосудистых заболеваний, что характерно для так называемой «сердечно-сосудистой революции», которая произошла в западных странах в конце 1970-х годов и которая происходит в восточноевропейских странах, начиная с 1990 г. Не будем здесь уточнять, с чем это связано. Придется слишком долго говорить и высказывать слишком много предположений.

Иванова: - Опубликовано, конечно, не две работы, а значительно больше. Но вы, наверное, имеете в виду только собственные работы. Я бы сказала, что универсальность снижения смертности является отличительной особенностью периода, начавшегося в 2005 г. Позитивная динамика отмечена и для мужчин, и для женщин; для всех без исключения возрастных групп; для всех причин смерти, включая неточно обозначенные состояния, и наконец, для всех регионов.

Вишневский: О причинах и ухудшения, и улучшения мы еще поговорим. Но я сначала хотел бы задать вопрос, относящийся вот к этой картинке, которая, как мне кажется, указывает на восстановительный характер нынешнего роста. Я пользовался расчетами Андреева (рисунок 8).

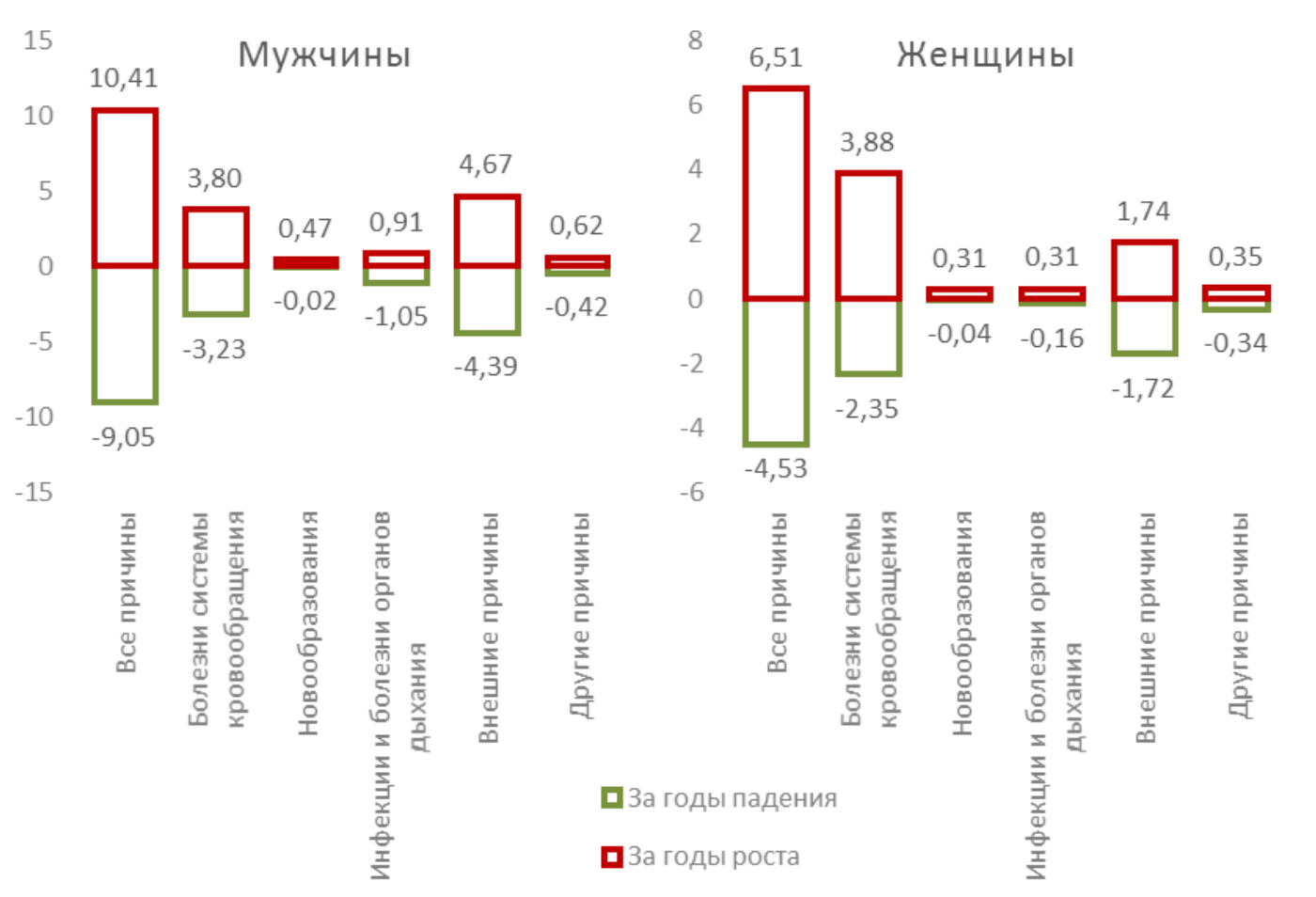

\section{Рисунок 8. Вклад изменения смертности от крупных классов причин смерти в снижение и рост ожидаемой продолжительности жизни, 1990-2013, лет}

Здесь показано изменение вкладов в продолжительность жизни изменений смертности от разных классов причин смерти за период с 1990 по 2013 г. За это время было два участка падения продолжительности жизни (1990-1994 и 1998-2003 гг.) и два участка 
роста (1995-1998 и 2004-2013 гг.). Всего 24 года: 11 лет падения и 13 лет роста. Когда столбики на графике идут вниз, продолжительность жизни сокращалась, когда вверх росла.

Вы видите, у мужчин, если говорить о смертности от всех причин смерти, высота верхнего и нижнего столбиков почти одинаковая - что потеряли, то и восстановили, прирост очень небольшой, немногим больше года. У женщин прирост около 2 лет. Примерно такая же картина и по отдельным причинам смерти - очевидный заметный выигрыш принесло только снижение смертности от болезней системы кровообращения у женщин и, в меньшей степени, у мужчин. В остальных случаях - почти чистая компенсация.

Школьников: - Да нет. Это не так. Дело в том, что нельзя смешивать то, что вы поставили вместе. То, что происходило до 2000 г., нельзя смешивать с тем, что происходило после 2000 г. Если посмотреть детально, то вы увидите, что это разные тренды. Вплоть до середины 50-х годов Россия была отсталой страной с высокой инфекционной смертностью, с высокой смертностью младенцев и детей. В 1980 г. этого уже не было, к этому времени Россия стала страной, сочетающей высокую смертность от хронических заболеваний (сердечно-сосудистых, в основном) в возрастах 40-60 лет, как в Восточной Европе (в Венгрии, например), с высокой смертностью от неестественных причин и насилия, отчасти как в Латинской Америке или среди афроамериканцев в США. А затем наступили времена больших колебаний смертности, которые сменились некой тенденцией более устойчивого улучшения. Причем, вполне возможно, что подействовали какие-то совершенно «естественные» факторы. Безусловно, в 2000-е годы был очень большой рост уровня жизни в стране, но была и диффузия нововведений. Представьте, как выглядит лечение давления архаичным папаверином по сравнению с современными препаратами, которые пришли с Запада. Можно заметить, что у нас существенная часть роста продолжительности жизни женщин вызвана снижением смертности в старших возрастах от болезней сосудов головного мозга, а это, в первую очередь, контроль артериального давления.

Иванова: - Владимир Михайлович совершенно прав, если посмотреть те же болезни системы кровообращения по возрастам, то там это будет совершенно точно видно. Я не разделяю мнения Анатолия Григорьевича, что отмечаемый рост - это лишь возвращение к ранее достигнутым уровням. Действительно, количественная оценка продолжительности жизни близка к тому, что было пять десятилетий назад, и повторно в 1986-1987 гг. Но возрастная кривая смертности, роль отдельных групп в формировании продолжительности жизни сейчас принципиально иная, хотя бы в отношении вклада младенческой и детской смертности. Соответственно и структура причин смерти не могла не претерпеть существенных изменений, и это хорошо видно, если перейти от классов причин смерти к группам и отдельным причинам.

Школьников: - Ну конечно. Просто нужен более детальный анализ.

Иванова: - Да, детализировать и по возрастам, и по причинам. В той группировке возрастов, которая на картинке, эти эффекты скрыты. Статистика - страшная сила. Доказать можно все, что хочешь.

Вишневский: - Ну, хорошо, посмотрим еще одну картинку, на этот раз по возрасту (рисунок 
9).

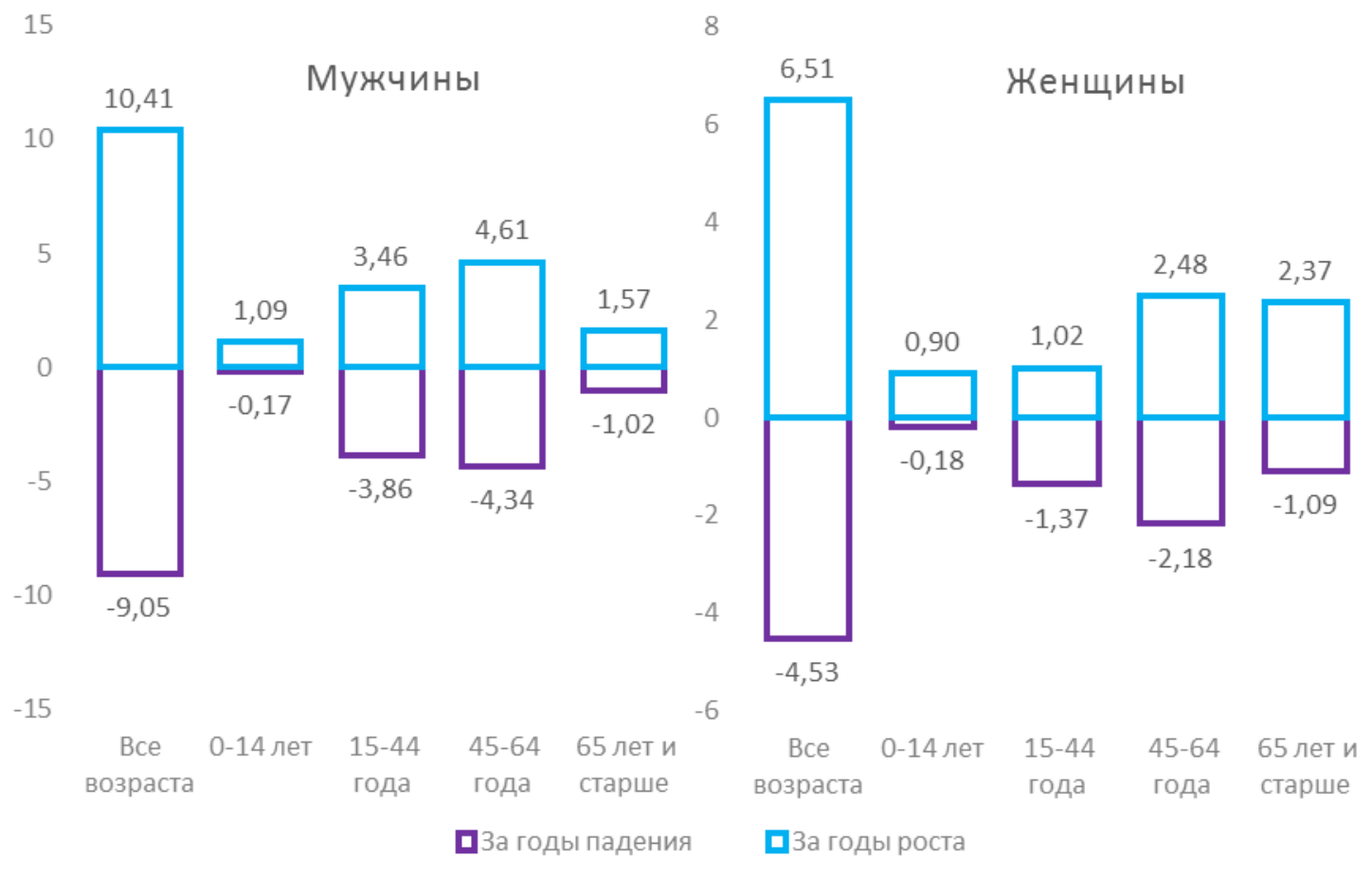

\section{Рисунок 9. Вклад изменения смертности по укрупненным возрастным группам в снижение и рост ожидаемой продолжительности жизни, 1990-2013, лет}

Результат, как мне кажется, очень похожий. Для всех возрастов, разумеется, такой же, как и для всех причин, а по возрастным группам - явный существенный выигрыш только у детей и у пожилых, в средних возрастах он либо небольшой, либо его вовсе нет. В такой важной группе, как 15-44 года, и у мужчин, и у женщин - чистый проигрыш. В среднем же - всего лишь компенсация понесенных ранее потерь, хотя и не буквальная.

Андреев: - Есть такая статья западных авторов: «Коэффициент суммарной рождаемости дает политикам дезориентирующие сигналы: не следует ли отказаться от использования этого показателя?» [Соботка, Лутц 2011: 444-471] - это такая хрестоматийная статья о проблемах данного показателя. Мне кажется, можно было бы написать статью с названием: «Показатель ожидаемой продолжительности жизни для календарного периода дает неверные сигналы обществу». Он и в самом деле дает неверные сигналы обществу. Потому что этот показатель слишком агрегированный. Из него можно сделать вывод, например, что Россия вернулась к уровням показателя в период антиалкогольной кампании или середины 1960-х. Но на самом деле современная ситуация в корне отлична и от антиалкогольной кампании и, тем более, середины 1960-х. Ожидаемая продолжительность жизни - слишком грубая характеристика. Она у нас растет...

Комаров: - Это преподносится как достижение.

Андреев: - Это преподносится как достижение, которое может устроить руководство. Но на самом деле под этим показателем лежат очень сложные процессы, противоречивые, разные. Мы никуда не вернулись: две страны с одинаковой продолжительностью жизни могут находиться в совершенно разной ситуации в области смертности. Нетрудно показать, 
что ситуация, в которой Россия была в 2003 г., и ситуация, в которой Россия находится сегодня, ни в коей мере не напоминает ситуацию в развитых странах мира ни на какой стадии их развития. Европа- $15^{2}$ никогда не имела такого типа смертности, который наблюдался в России в 2003 г. и который наблюдается сегодня. Это совершенно иное явление.

Вишневский: - Евгений Михайлович, но все же, что такое продолжительность жизни? Это измеритель смертности сегодняшнего дня.

Андреев: - Это плохой измеритель смертности, потому что можно рисовать две совершенно разные кривые смертности с одинаковой продолжительностью жизни. Это слишком грубая характеристика, чтобы на неё ориентироваться, по крайней мере в кругу профессионалов.

Вишневский: - Я с этим не согласен, хотя и признаю ограничения этого показателя, связанные с тем, что обычно мы его используем применительно к календарным периодам. Но прямая аналогия с коэффициентом суммарной рождаемости, который начинает давать неверные сигналы, когда изменяется календарь рождений, мне кажется неправомерной.

Так или иначе, в результате нашего обсуждения вырисовываются две позиции. Я утверждаю, что в целом можно говорить лишь о восстановительном росте и не более того. Восстановительный рост, возвращение к тому, что уже было достигнуто - этого не сложно добиться...

Школьников: - А что же мы тогда не могли добиться этого восстановительного роста в течение 40 лет? Восстановления уровня продолжительности жизни 1965 г. не происходило до середины 2000-х. Мы много десятилетий не могли добиться восстановительного роста.

Вишневский: - Как не было роста? Ведь в конце 80-х мы вернулись к тому, что было в середине 60-х. Но в целом, как я говорил и говорю, было топтание на месте, и я считаю, что это топтание продолжается. Это одна позиция. Но есть и другая - Владимира Михайловича, Аллы Ефимовны и, кажется, Евгения Михайловича, - возможно, ее разделяют и другие. Она заключается в том, что речь идет не о простом восстановлении того, что было достигнуто ранее, а о принципиально новых тенденциях. Наличие двух позиций всегда хорошо, это стимулирует обсуждение, к которому я всех и призываю.

Комаров: - По первому вопросу, мне кажется, мы должны сделать вывод, что не надо эту динамику продолжительности жизни расценивать как большой успех. От этого надо предостеречь, потому что у нас это все время используется для демонстрации успехов, что вот, дескать, мы достигли, причем кто? Минздрав? Министр здравоохранения Скворцова выходит и говорит, что «мы достигли», и Президент сидит и её слушает.

Андреев: - Но Анатолий Григорьевич выступал недавно и зачитывал, если мне не изменяет память, сообщение о том, что Россия вошла в число успешных стран по продолжительности жизни по версии агентства Блумберг, но только заняла среди этих стран последнее место по этому показателю.

215 стран, входивших в Европейский союз до его расширения в мае 2004 г. 
Вишневский: - 51-е место. О вхождении в список объявил Путин, но о пятьдесят первом месте он не сказал. Он только отметил, что продолжительность жизни у нас впервые превысила 70 лет, что по нынешним временам не так уж и много. Это и 30 лет назад было немного.

«Здесь мы сталкиваемся с одной из наиболее острых социальнодемографических проблем сегодняшнего дня. После нескольких десятилетий быстрого снижения смертности и роста продолжительности жизни, начиная примерно с середины шестидесятых годов, наступил длительный период «топтания на месте». Сохранялась, а в некоторых случаях и росла и без того относительно высокая смертность, особенно мужчин в рабочих возрастах, увеличивалось отставание СССР по показателям смертности и продолжительности предстоящей жизни от большинства экономически развитых стран мира. <..> Смертность детей в возрасте до 1 года у нас значительно выше, чем в крупных капиталистических странах. Средняя продолжительность жизни никак не достигнет 70 лет, тогда как в США и Франции она составляет 75 лет, в Японии - 77».

ГВишневский 1986: 71-72].

\section{НАДЕЖНА ЛИ НАША ИНФОРМАЦИЯ О СМЕРТНОСТИ?}

Комаров: - Мы говорим о тенденциях смертности, но все ли мы о них знаем? То, что сейчас происходит и о чем мы спорим, связано и с теми колебаниями, которые мы сейчас наблюдаем в регистрации этих случаев в здравоохранении. Три момента я бы выделил:

- во-первых, действительно, мы пропустили второй эпидемиологический переход и эпидемиологическую революцию, когда начали доминировать факторы риска и хронические неспецифические болезни;

- второе, что нужно выделить, это популяционные процессы, которые идут сами по себе, по определенным закономерностям;

- $\quad$ третий процесс - это все-таки давление на практику регистрации извне. Причина такого прессинга в том, что сейчас все, начиная от Минздрава и кончая властью, заинтересованы в том, чтобы у нас ситуация улучшалась. Поэтому прессинг идет, и я думаю, что он идет и на органы статистики.

Возьмите здравоохранение. Вот, например, выделили 80 млрд рублей на периодические профилактические осмотры, мы хотим оттуда извлекать данные о заболеваемости. Можно за короткий промежуток времени поставить диагноз диабет или рак, или даже простую гипертензию? Это будет «липа» полная. Ведь надо же в динамике смотреть, понимаете. То, что сейчас происходит в регистрации всех этих случаев, в том числе и летальных исходов, мне кажется, это «липа», в том числе и в результате давления сверху. Так, есть данные о том, что в профилактических периодических осмотрах приписки достигают местами до $70 \%$.

Школьников: - Губернаторам регионов показатели смертности включили в число важных отчетных показателей. Наверное, это хорошо, потому что губернаторы контролируют все вопросы, от которых смертность зависит (от профилактики и лечения до преступности и 
безопасности жизни).

Иванова: - Губернаторам в качестве показателя поставили общий коэффициент смертности.

Школьников: - Жаль, это совсем слабый показатель.

Вишневский: - Но все-таки смерть констатируется, возраст же не подделывают. Ну, допустим, причины смерти ладно, но...

Комаров: - Причины смерти легко подменить.

Вишневский: - Ну, хорошо, причины, а как же возраст?

Школьников: - Ну, как может быть «липа»? Какой тут механизм вранья? Для занижения смертности нужно число смертей фальсифицировать.

Комаров: - Хорошо, сейчас объясняю. Вот, например, профессор Павел Андреевич Воробьев три раза ездил на Сахалин на своей машине и останавливался везде. И он говорит, что люди в Сибири умирают и их не регистрируют. Их не регистрируют, их хоронят просто так. Почему? Во-первых, потому что для регистрации нужно за 200 км везти к врачу, чтобы он констатировал смерть.

Ермаков: - Почему, по закону это и фельдшер может сделать.

Комаров: - И к фельдшеру за 70 км никто не возит. Это раз. Второе, если не регистрируют, тогда пенсия продолжает идти. То есть фактически здесь очень много причин; в результате того, что мы развалили систему здравоохранения, получается, что идет процесс недорегистрации. Поэтому здесь возможно все что угодно, в том числе и приписки.

Немщов: - А как велик процесс недорегистрации?

Комаров: - Думаю, процентов 10 - это минимально.

Ермаков: - Но это и не делает погоды.

Иванова: - У нас нет исследований полноты регистрации смертей, а без них такие оценки сделать нельзя.

Школьников: - Юрий Михайлович, но если бы это было так, тогда улучшения смертности было бы больше в Сибири, чем в Москве, а мы наблюдаем обратное.

Комаров: - Понимаю, понимаю. Второе, что есть в регистрации смертности: вы же знаете, что смерть регистрируется у нас по месту жительства, по месту прописки.

Bce: - Не совсем так.

Андреев: - По месту наступления события, как правило.

Комаров: - Как правило, да, но все-таки потом свидетельство о смерти пересылается.

Ермаков: - Не пересылается, Юрий Михайлович.

Андреев: - Пересылается только в рамках области. 
Комаров: - В рамках одной области, а в другую область не передается. Значит, если человек умер из другого места, он входит в отчет этой области.

Ермаков: - Исключение есть для солдат, их смертность учитывается по месту прописки.

«Государственная регистрация смерти производится органом записи актов гражданского состояния по последнему месту жительства умершего, месту наступления смерти, месту обнаружения тела умершего, месту нахождения организации, выдавшей документ о смерти, месту жительства родителей (одного из родителей), детей, пережившего супруга или по месту нахождения суда, вынесшего решение об установлении факта смерти или объявлении лица умершим».

[Федеральный закон №143-Ф3, ст.65].

Вишневский: - Давайте попробуем подытожить эту часть нашего разговора. С одной стороны, сам факт роста продолжительности жизни после 2003 г. вроде бы никем не оспаривается, хотя есть расхождения в том, как трактовать этот рост: как, в основном, возврат к тому, что уже было, или как свидетельство перелома тенденции. Но есть еще и весьма существенные дополнительные соображения, касающиеся достоверности и точности исходных оценок смертности, лежащих в основе всех последующих рассуждений. Есть объективные пределы точности, не все можно учесть на 100\%, но разумеется, нельзя исключать и намеренных подтасовок.

Если демографические показатели рассматриваются как свидетельство успешности или неуспешности работы губернатора и власти вообще, то появляется заинтересованность в том, чтобы эти показатели были получше. У нас это всегда было. В советское время просто засекречены были почти все данные о смертности, а сейчас они не засекречены, но могут быть фальсифицированы. Это не исключено. Мы не знаем, как это контролировать, наверно, надо думать об этом. Какие-то методы сравнительного анализа могут помочь выявить вольные или невольные искажения, но пока, во всяком случае, существует представление, что имеющиеся оценки не на 100\% надежны. Если говорить о злонамеренных искажениях, то, возможно, они и есть, но откровенно говоря, мне не представляется, что в России может быть очень большой масштаб фальсификации информации о смертности в целом, скорее, это вероятно при кодировании причин смерти, но к этому мы еще вернемся.

Шишкин: - Здесь мы должны, мне кажется, вместе констатировать, что фальсификация имеет место, но вопрос в масштабе этой фальсификации. Существенен ли он для обсуждения причин роста продолжительности жизни или не существенен. Мне кажется, что несущественен.

\section{ВЕЛИКИ ЛИ РЕГИОНАЛЬНЫЕ РАЗЛИЧИЯ В СМЕРТНОСТИ?}

Ермаков: Очень важную вещь, кажется, никто не отметил. Россия - это больше 80 территорий, и более чем для 60 территорий рост продолжительности жизни весьма сомнительный. Показатель по стране мы вытаскиваем за счет Москвы, за счет ХантыМансийского АО и черноземных районов, начиная с Ростова и южнее. 
Андреев: Нет-нет, это не совсем так. Рост универсален.

Иванова: Рост есть везде, правда, он разный, разный по масштабу, но есть везде.

Ермаков: Все статистические показатели имеют «коридорчики». Росстат никогда эти коридорчики не рассчитывал. А идеология оценки сейчас - даже слова «доверительный интервал» убрали. Сейчас вообще рассчитывают uncertainty interval (интервал неопределенности) совсем другими методами, в частности бутстрепом. О чем тогда мы говорим по первому вопросу? Мы не знаем ответа, если строго по-научному.

Школьников: Для России в целом нет улучшения?

Ермаков: Мы не знаем, есть для России устойчивый рост или нет, - он вроде есть, а вроде и нет. Я считаю, что нет никого роста. И у меня целая куча есть аргументов. Ну у кого-то есть аргументы за то, что есть устойчивый рост. Вот Алла Ефимовна только что сказала, что рост есть везде, только разный, и так далее.

Андреев: - Маленький комментарий. Вот в этой книжке [Население России... 2014] написано, что мы посчитали абсолютные межрегиональные различия ожидаемой продолжительности жизни за период после 1989 г.: они действительно выросли и достигли своего максимума в 2004 г., а после 2004 г. они стабильны и не меняются. Абсолютная межрегиональная разность (абсолютная разность в продолжительности жизни, взвешенная по численности населения) после 2004 г. стабильна. В книге есть соответствующий график.

Вишневский: - По-вашему, это говорит в пользу достоверности?

Андреев: - Это говорит о том, что межрегиональные различия не растут.

Вишневский: - А говорит ли это в пользу достоверности?

Школьников: - Нет, они должны сокращаться.

Шишкин: - Совсем не обязательно должны сокращаться, ведь другие различия между регионами, и в частности экономические, не сокращаются.

Школьников: - Вы думаете, что экономический рост - эквивалент роста продолжительности жизни?

Шишкин: - Нет, конечно. Я лишь хочу подчеркнуть, что данные о сохранении межрегиональных различий в ожидаемой продолжительности жизни не могут априори расцениваться как недостоверные.

Андреев: - Хочу заметить, что в регионах, где нет устойчивого роста ожидаемой продолжительности жизни, находится очень малая часть всего населения. В конечном итоге, половина населения России живет в 27 субъектах на 6\% территории, население всего Дальневосточного Федерального округа ненамного больше населения Санкт-Петербурга, а Сибирского - примерно равно населению Москвы и Московской области. А областей и там, и там очень много.

Иванова: - Конечно, рост продолжительности жизни есть и с учетом интервалов неопределенности, и без их учета, это не имеет значения. Достаточно посмотреть на 
масштабы прироста с 2004 или 2005 г., кто как считает. В целом по РФ с учетом численности населения страны оценки интервалов неопределенности не имеют особого смысла.

Что касается региональной статистики, я хотела об этом сказать, но Сергей Петрович меня опередил. Действительно, ситуация нетипична. Известно, что всегда рост ожидаемой продолжительности жизни сопровождался сокращением ее региональной вариации, потому что быстрее росла продолжительность жизни на неблагополучных территориях, где отклик на стимулы снижения смертности и начинался раньше, и был по масштабу более заметным. Сейчас мы не имеем сокращения регионального разброса: за период с 2004 г. он практически стоит на месте и для мужчин, и для женщин, потому что и относительно благополучные, и неблагополучные территории ведут себя по-разному. Часть неблагополучных территорий действительно демонстрирует рост продолжительности жизни опережающими темпами, но часть практически стоит на месте и занимает то место, которое занимало всегда. Это не только пресловутая Тува, но и другие территории на северо-западе и в Восточной Сибири. Если смотреть динамику по годам, то в целом по России на протяжении практически десятилетнего периода отмечалась колебательная динамика прироста продолжительности жизни, т.е. более высокий прирост сменялся меньшим, а региональная развертка этих колебаний свидетельствует, что примерно 10\% территорий демонстрировали в отдельные годы сокращение продолжительности жизни. T.е. фундаментальная основа для устойчивого роста продолжительности жизни есть далеко не на всех территориях. Нельзя, конечно, сводить позитивный тренд только к Москве и Ханты-Мансийску, география устойчивого сокращения смертности значительно шире; правильнее было бы говорить об анклаве территорий, не имеющих основы для устойчивой динамики, а это, по нашим оценкам, примерно четверть российских территорий. И если уже переходить к причинам, а именно к роли здравоохранения, то далеко не везде равномерно здравоохранение улучшалось, и в результате предпринятых мер разрыв в доступности и качестве услуг не сократился, а увеличился.

\section{КАКИЕ ПОЛОВОЗРАСТНЫЕ ГРУППЫ БОЛЬШЕ ДРУГИХ ОПРЕДЕЛЯЮТ РОССИЙСКОЕ ОТСТАВАНИЕ?}

Вишневский: - Второй вопрос: есть ли какие-то половозрастные группы, которые больше других определяют российское отставание? С детскими возрастами у нас, кажется, все более или менее благополучно.

Андреев: - Относительно благополучно. Все показатели смертности в два-три раза выше, чем в Европе, но не в шесть-восемь раз, как в возрастах 25-44 года у мужчин, и динамика стабильная.

Вишневский: - Младенческая смертность сейчас в Европе такая низкая, что даже если она у нас в два раза выше, то это 7-8\%. А ведь еще 30 лет назад было 21\%о при том, что в Японии было 5\%. Тогда это скрывалось.

Ермаков: - У нас тогда даже наказывали за озвучивание данных в советское время о младенческой смертности. 
Комаров: - Меня в свое время на ковер вызывали за младенческую смертность.

Ермаков: - На коллегии Минздрава заведующего отделом обычного института уволили за это. Вот так.

Вишневский: - В 1986 г. я пытался в статье в журнале «Коммунист» назвать эти цифры, и редакция не возражала. А вы помните, какой вес имел тогда этот журнал. Но тогдашнее ЦСУ СССР наложило вето на публикацию данных, и даже главный редактор журнала, член ЦК КПСС, не смог преодолеть этот запрет. Осталась только фраза: «Смертность детей в возрасте до 1 года у нас значительно выше, чем в крупных капиталистических странах».

Сейчас положение с младенческой смертностью намного лучше. Конечно, и сейчас мы отстаем, но есть позитивная динамика, мы догоняем. А вот со смертностью трудоспособного населения, особенно мужского, положение сложнее. Есть у нас эта проблема как отдельная или нет?

Ермаков: - Проблема есть. Я три года отработал в системе ОМС в Московской области, там есть эксперты - они все профессионалы высокого уровня, - которые рассматривают сложные случаи: человека правильно обслуживают или неправильно, нарушили какие-то нормы или не нарушили и т.д. И вот они мне рассказали, и я проверил. У мужчин в возрасте 30-45 лет очень часто первый контакт с медицинским учреждением в связи с сердечнососудистым заболеванием происходит через скорую помощь. Люди не следят за своим здоровьем.

Комаров: - Есть еще одна особенность - у мужчин те же самые заболевания протекают более агрессивно и более тяжело, чем у женщин.

Ермаков: - Это тоже правильно. Там одно на другое накладывается.

Вишневский: - Смертность взрослых от сердечно-сосудистых заболеваний у нас более ранняя, чем на Западе. А заболеваемость? Для того чтобы умереть, нужно заболеть. У них позже заболевают или они лучше лечат?

Иванова: - О заболеваемости у нас мы практически ничего не знаем, потому что статистики по этому поводу нет, она констатирует лишь контакты со здравоохранением.

Шишкин: - Если не зафиксировано, считайте, что и не заболел.

Комаров: - Могу по этому поводу сказать, что наши сельские жители скоро будут самыми здоровыми в мире. Потому что у нас заболеваемость регистрируется, как вы знаете, по обращаемости, а там некому регистрировать.

Ермаков: - Я статистикой здравоохранения занимаюсь достаточно давно, и могу сказать: все таблицы по заболеваемости, грубо говоря, бессмысленны. Объясняю: выделяются три группы: дети 0-14 лет, дети 15-17 лет и все остальные возраста в одну группу взрослые (18 лет и старше). В целом ряде таблиц пишется «первичное обращение». Что это такое? Больной пришел в поликлинику, его записали, но сказали: «у вас же медсанчасть есть, вы бы туда сходили». Он идет, его и там записали, но посоветовали сходить в кардиоцентр его и там записали. Даже если каждый раз диагноз правильный, идет сильное преувеличение реального числа обратившихся. 
Школьников: - Есть исследования распространенности болезней на основе обследований здоровья и факторов риска. А официальные данные о заболеваемости, очевидно, плохие. Но есть также гораздо менее очевидные, но важные проблемы и в данных о смертности, которые считаются достаточно надежными.

Возьмите вопрос о ранней сердечно-сосудистой патологии и огромном количестве российских смертей от сердечно-сосудистых заболеваний в возрасте до 60 лет. По этому поводу есть две точки зрения сейчас, и каждая из них имеет свои основания.

Есть точка зрения Давида Заридзе и его коллег, которые проводили в Барнауле и Томске серьезное исследование, опубликованное в журнале «Lancet» [Zaridze et al. 2009; Zaridze et al. 2014]. Это исследование, основанное на микроданных, указывает на то, что высокая и ранняя смертность от сердечно-сосудистых заболеваний - статистический артефакт, и что на самом деле - это смерти от отравлений алкоголем, которые просто неправильно закодированы как сердечно-сосудистые смерти. Это - одна точка зрения. Другую точку зрения, выражают Дэвид Леон, Мартин Макки, Евгений Михайлович Андреев и я. Мы провели другие исследования в других местах России, которые говорят, что да, может быть, есть некоторый перекос в статистике причин смерти, но он невелик и далеко не объясняет всю преждевременную сердечно-сосудистую сверхсмертность россиян [Leon et al. 1997; McKee, Shkolnikov, Leon 2001]. С другой стороны, мы увидели на данных Ижевска, что, с точки зрения развития атеросклероза, много пьющие имеют более низкий холестерин и лучшее состояние сосудов. Откуда же в России такая смертность от сердечнососудистых заболеваний среди 40-50-летних? И если эти смерти действительно от сердечно-сосудистых заболеваний, значит есть какие-то другие, пока неизвестные, физиологические механизмы, которые нужно изучать. Чтобы это выяснить, сейчас ведется англо-российско-норвежское исследование, которое проходит в Архангельске и Новосибирске и стоит больших денег.

Вишневский: - Вроде бы все согласны, что наша особая проблема - мужская смертность в средних возрастах. Это верно?

Комаров: - Да, конечно, несомненно.

Вишневский: - У женщин в это смысле значительно лучше. Но есть еще вопрос о том, что все же происходит после 60 лет? Это важно в связи с обсуждением вопроса о возрасте выхода на пенсию. С каким состоянием здоровья наши люди достигают этого возраста?

Комаров: - Минздрав уже на протяжении сорока лет не заказывает исследования о здоровье населения. Раньше всегда проводились эти исследования в связи с переписями населения. Теперь - нет. Только сейчас Федеральным агентством по науке будет заказано исследование - мониторинг здоровья. Идет обсуждение этого проекта, уже вышли на договора даже. Исследование будет проводить один из крупнейших институтов нашей страны. Его предполагается вести не по всей территории, а на типичных представителях. Будет проведена классификация территорий, из каждой группы территорий будет выбран какойто представитель, и по определенным критериям, которые будут разработаны специально, будет вестись вся работа.

Вишневский: - Сергей Петрович, у меня к вам вопрос. А как в других странах, тоже по WWW.DEMREVIEW.HSE.RU 
укрупненным группам или там все-таки есть по той же заболеваемости?

Ермаков: - Первичные данные собираются и обобщаются - я сейчас говорю не о свидетельствах о смерти или амбулаторных картах - в табличной форме со стандартной группировкой ВО3: 0-1, 1-4, далее либо пятилетние группы, либо 85+, либо даже сейчас 95+ в развитых странах.

Вишневский: - Это по заболеваемости?

Ермаков: - Понимаете в чем дело, у них даже термина такого нет. У них страховые компании лечат людей, и страховые компании частные, они не делятся друг с другом первичной информацией. Еще в 90-е годы, в начале 90-х годов, когда премьером Черномырдин был, приехал американец и показывал информационную систему, для которой, по договоренностям со страховыми фирмами, ему давали повозрастные данные. И он показывал, какая в разных штатах заболеваемость. Ситуация примерно та же. Ему никто первичных данных не давал, ему давали сгруппированные по возрастам, по стандартным возрастным группам данные. У него частная фирма небольшая, он и еще два человека. Они зарабатывали столько, что могли даже ездить в Россию и учить нас жизни вообще и медицинской статистике, в частности.

Вишневский: - Все же это тоже важный вопрос с точки зрения того, что мы можем порекомендовать. Может быть, надо сказать, что этих данных нет, что они необходимы и надо думать, как их получить.

Школьников: - Нужна не статистика заболеваемости, а статистика распространенности, нужны биологические данные, давление, холестерин, маркеры воспаления и прочее. Нужно, чтобы все было так, как в наиболее развитых странах. Ничего придумывать не надо, все уже придумано.

Иванова: - Сейчас по этой программе «Steps» будет работать институт профилактической медицины.

Школьников: - Вот это очень хорошо, это и нужно.

Комаров: - В Голландии это так называемые Sentinel Stations, в Штатах - отдельные исследования, проводимые Центрами по контролю за болезнями.

Андреев: - В США есть База данных Centers for Disease Control and Prevention (Центры по контролю и профилактике заболеваний).

Иванова: - Хочу вернуться к теме заболеваемости. Вопрос: действительно у нас умирают раньше, потому что заболевают раньше? Про кардиологию ответить на этот вопрос нельзя, нет статистики. А вот про рак сказать можно. Там есть нормальная статистика заболеваемости, она фиксируется исключительно диспансером, где верифицируется диагноз, нет смешения обращений в разные медицинские учреждения, как при других заболеваниях, расчет идет на основании событий у физических лиц, и пациент «привязан», так сказать, к определенной территории.

Онкологическая статистика отчетливо свидетельствует, что пациенты умирают раньше, потому что их выявляют позже. 
Комаров: - И есть индикаторы очень хорошие: одногодичная выживаемость, пятилетняя выживаемость, десятилетняя выживаемость.

Иванова: - Если в онкологи так, то почему в кардиологии должно быть по-другому? Я думаю, что так должно быть в отношении всех хронических заболеваний.

Вишневский: - Можно предположить, что, поскольку от сердечно-сосудистых заболеваний стали меньше умирать, то больше людей доживают до своего рака. Значит, они и заболевают позже...

Комаров: - Но от рака все-таки раньше умирают.

Андреев: - У нас - да, но в развитых странах от рака умирают ненамного раньше, чем от сердечно-сосудистых болезней.

Вишневский: - Это верно, средний возраст смерти от рака повысился. Но благодаря чему? Какие здесь могут быть варианты? Либо позже умер, потому что позже заболел раком, вследствие того, что не умер до этого от сердечно-сосудистого или какого-либо иного заболевания, с которым научились бороться; либо позже умер, потому что сейчас лечат и продлевают жизнь онкологическим больным. Это все-таки разные вещи, и хорошо бы в них разобраться.

Комаров: - Ну, рак у нас сейчас лечат не по полной программе, мы же отказались от закупок противоопухолевых препаратов, а своих у нас нет.

Вишневский: - Допустим, мы не закупаем, но есть мировой опыт. Ясно, что во многих странах люди с диагностированным раком живут дольше.

Комаров: - Смотря, какие формы.

Вишневский: - У нас есть данные о среднем возрасте смерти от каждой причины, и видно, что средний возраст смерти от рака значительно вырос во всех странах.

Комаров: - Это средняя температура по больнице.

Вишневский: - Конечно, средняя величина - статистическая характеристика, она обобщает, но все же о чем-то она говорит. Если средний возраст смерти вырос значительно, значит, что-то сдвинулось.

Иванова: - Это в целом по раку, а по отдельным локализациям картина совершенно другая.

Вишневский: - По отдельным может быть, мы сейчас не в состоянии вникнуть в детали. Но разве не важна ситуация в целом, по всему классу причин? В некоторых западных странах стандартизованные коэффициенты смертности от рака и от сердечно-сосудистых заболеваний сравнялись, по крайней мере у мужчин. При этом средний возраст смерти и от того, и от другого сильно вырос. Средний возраст смерти от рака существенно выше не только по сравнению с тем, каким он был несколько десятилетий назад, но и по сравнению с тем, каким он был тогда для смертности от сердечно-сосудистых болезней.

Андреев: - В США средний возраст смерти от рака лишь немного ниже, чем от болезней системы кровообращения: в 2010 г. у мужчин - 79,6 и 75,8 года, у женщин - 84,7 и 76,2. 
Школьников: - Выше, это верно, хотя многое от страны зависит. Но в целом и для рака, и для сердечно-сосудистых заболеваний средние ожидаемые возраста смерти в наиболее развитых странах высокие.

Вишневский: - В любом случае, нам надо было бы иметь более полную информацию о заболеваемости по возрасту. Или хотя бы обращаемости. Как бы ни совершенен был показатель обращаемости, но возраст есть возраст, что-то он отразит. Он должен как-то фиксироваться и обрабатываться. Что для этого надо сделать?

Кваша: - Об этом говорится десятилетиями.

Школьников: - Это очевидные вещи.

Андреев: - Мы об этом писали еще в 1975 г.

Вишневский: - Но это не значит, что об этом не надо писать сейчас. Капля камень точит.

Иванова: - Маленький комментарий. Все-таки какие-то изменения произошли: в статистике заболеваемости по обращаемости возрастную группу 18 лет и старше разделили на «до трудоспособного» и «старше трудоспособного» возраста. Поэтому с 2012 г. есть возможность анализа более детальных данных. Кроме того, как вы знаете, в свидетельстве о смерти должна указываться не только причина смерти, но и продолжительность заболевания, ставшего причиной смерти.

Школьников: - На самом деле, мировой опыт показывает, что статистика заболеваемости не дает полной картины, а нужна статистика распространенности, причем для этого нужны такие исследования, какие делает в Штатах NHANES (National Health and Nutrition Examination Survey) или в Англии ELSA (English Longitudinal Study on Aging). Было бы отлично, если бы подобные исследования были заложены и в России. Нужен какой-то мониторинг объективных показателей здоровья на большой репрезентативной выборке. У нас же проблем здоровья и смертности намного больше, чем в Америке, значит, наверное, нам хотя бы что-то нужно тратить на мониторинг здоровья, хотя бы в 10 раз меньше. Но не 0 же тратить на это!

Харькова: - Нужно что-то по типу бюджетных обследований домохозяйств.

Школьников: - Да, заложить такое исследование, и не так, как сейчас, когда Центр профилактической медицины должен по конкурсу выбирать, кто будет в той или иной области проводить выборочные исследования. Там тот, кто назначит меньшую цену, тот и будет проводить, независимо от компетентности.

Комаров: - Сейчас уже не так.

Школьников: - Тем не менее, два дорогостоящих исследования, которые могли бы быть полезны, уже были таким образом проведены.

Андреев: - Владимир Михайлович не пояснил, что американские обследования серии NHANES, о которых шла речь, охватывают большие выборочные совокупности, за которыми идет панельное наблюдение, они регулярно обновляются, ремонтируются, и об этих людях все известно. 
Школьников: - Они повторяются каждый год.

Вишневский: - Пока вы знаете, что в нашей микропереписи сняли все или почти все вопросы о здоровье.

Андреев: - Но, может, и не зря, потому что от них толку немного.

Вишневский: - Будет или не будет толк, об этом можно спорить, но бывают вещи, которые имеют символическое значение. Какие-то экономические вопросы, которые задаются при микропереписи, тоже далеко не идеальны, толк от них тоже может быть поставлен под сомнение, но их ставят, потому что это считается важным. А здоровье считается неважным, поэтому вопросы о здоровье первыми попадает под нож.

Шишкин: - Тут, возможно, есть и другое соображение. Английский исследователь Кристофер Дэвис только что опубликовал статью «Российский айсберг смертности». У нас такое громадное число заболеваний, очень большие масштабы скрытой заболеваемости, что если это сделать достоянием гласности, то станет очевидным, что тех усилий, тех ресурсов системы здравоохранения, которыми она располагает, просто не хватит.

Комаров: - А кто этого не знает?

Шишкин: - Это станет достоянием всеобщим, этого и не хотят, потому и не проводят такого исследования.

Комаров: - Когда раньше проводили изучение состояния здоровья и прежде всего заболеваемости и распространенности, то вводили так называемый «фильтр», т.е. экспертизу нуждаемости в медицинской помощи. Не при каждом заболевании нужно, чтобы человек пошел к врачу, такой фильтр позволяет отсеивать тех, кто в этом не нуждается, и выявлять тех, кому действительно нужна помощь медицины. Это во времена Богатырева было. Я в этом участвовал и знаю хорошо, как это делалось.

Вишневский: - В свое время Кричагин очень выступал против диспансеризации. Она у нас сейчас пошла в гору...

Комаров: - По поводу диспансеризации, вообще, я должен сказать, что Минздрав сильно лукавит во всех отношениях и неправильно информирует высшие власти. С их подачи и Путин теперь заговорил о диспансеризации, хотя речь идет всего лишь о периодических профилактических осмотрах. Диспансеризация - это совсем другое. Если такие осмотры всегда массовые, то диспансеризация всегда индивидуальна. Берется человек на диспансерный учет, за ним ведется диспансерное наблюдение и оздоровление. Вот же что самое главное. А деньги выделены только на осмотры. 80 млрд рублей каждый год.

\section{КАКИЕ ПРИЧИНЫ СМЕРТИ ВНОСЯТ НАИБОЛЬШИЙ ВКЛАД В РОССИЙСКОЕ ОТСТАВАНИЕ?}

Вишневский: - Предлагаю двигаться дальше и рассмотреть все тот же общий вопрос, но теперь в терминах причин смерти. Позиция нашего института, которую мы не раз обосновывали, заключается в том, что в России есть две главные группы причин, которые 
в решающей степени определяют наше отставание. Во-первых, это болезни системы кровообращения, но не смертность от них вообще, а высокая смертность в молодых и средних возрастах, потому что в старших возрастах смертность от этих болезней более или менее естественна. А во-вторых - внешние причины смерти.

Комаров: - Нужно говорить не о сердечно-сосудистых вообще, а о сердечно-сосудистых у мужчин.

Вишневский: - Посмотрите, вот две таблицы, они относятся к 2010 г. Вверху мужчины, внизу - женщины (таблицы 2 и 3). Здесь сравниваются табличные числа смертей от разных причин в разных возрастах до 70 лет. За стандарт снова принят ЕC-15. Темно-красная заливка указывает на максимальное отличие. Цифра в правом нижнем углу первой таблички (более 46 тыс.) означает, что из каждых 100 тыс. мужских смертей в России более 46 тыс. преждевременны в том смысле, что в ЕС-15 они случились бы в возрасте старше 70 лет. Из этих 46 тыс. около 20 тыс. - смерти от сердечно-сосудистых заболеваний и 17 тыс. - от внешних причин. Всего, стало быть, 37 тыс. из 46. У женщин, конечно, положение лучше, - я согласен с вами, Юрий Михайлович, у них не 46 тыс. преждевременных (в указанном смысле) причин, а всего 21 тыс., но это тоже немало.

Таблица 2. Избыточные табличные числа мужских смертей в возрасте до 70 лет в России, по сравнению с ЕС-15, на 100000 мужчин, умирающих во всех возрастах и от всех причин, 2010

\begin{tabular}{|c|c|c|c|c|c|c|c|c|}
\hline Возраст & 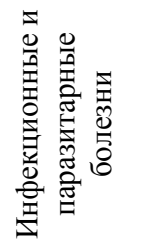 & 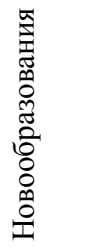 & 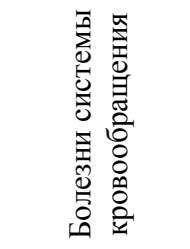 & 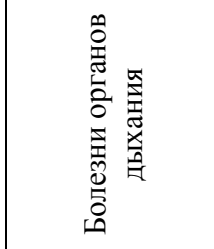 & 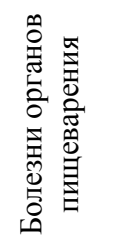 & 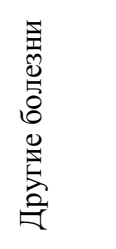 & 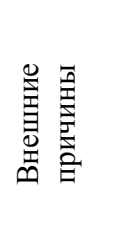 & 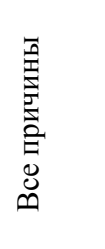 \\
\hline 0 & 99 & 6 & 6 & 176 & 6 & 936 & 97 & 1326 \\
\hline $1-4$ & 28 & 19 & 3 & 58 & 4 & 97 & 154 & 362 \\
\hline 5-9 & 6 & 13 & 3 & 11 & 2 & 45 & 160 & 240 \\
\hline $10-14$ & 3 & 10 & 5 & 7 & 2 & 26 & 171 & 225 \\
\hline $15-19$ & 16 & 18 & 29 & 18 & 8 & 63 & 685 & 837 \\
\hline $20-24$ & 82 & 22 & 117 & 41 & 29 & 156 & 1603 & 2049 \\
\hline $25-29$ & 147 & 27 & 207 & 63 & 57 & 193 & 1744 & 2437 \\
\hline $30-34$ & 190 & 35 & 375 & 95 & 100 & 197 & 1752 & 2742 \\
\hline $35-39$ & 242 & 78 & 685 & 168 & 145 & 217 & 1845 & 3380 \\
\hline $40-44$ & 289 & 158 & 1225 & 248 & 179 & 258 & 1991 & 4348 \\
\hline $45-49$ & 298 & 317 & 1948 & 360 & 191 & 275 & 2013 & 5402 \\
\hline $50-54$ & 254 & 406 & 2762 & 442 & 176 & 243 & 1806 & 6089 \\
\hline $55-59$ & 196 & 483 & 3570 & 492 & 131 & 115 & 1474 & 6462 \\
\hline $60-64$ & 111 & 47 & 4403 & 507 & 59 & -65 & 994 & 6056 \\
\hline $65-70$ & 2 & -803 & 4649 & 386 & -26 & -353 & 534 & 4390 \\
\hline Всего & 1964 & 836 & 19987 & 3068 & 1063 & 2402 & 17023 & 46344 \\
\hline Число избы & ных смер & & олее 1000 & $500-1000$ & & & & \\
\hline
\end{tabular}


Таблица 3. Избыточные табличные числа мужских смертей в возрасте до 70 лет в России, по сравнению с ЕС-15, на 100000 женщин, умирающих во всех возрастах и от всех причин, 2010

\begin{tabular}{|c|c|c|c|c|c|c|c|c|}
\hline Возраст & 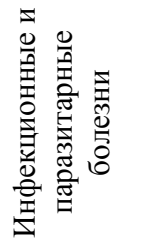 & 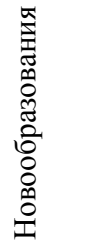 & 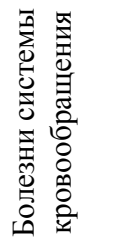 & 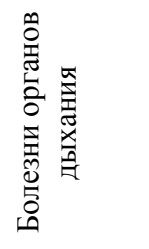 & 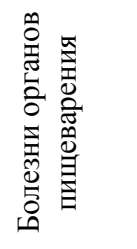 & 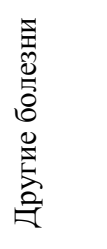 & 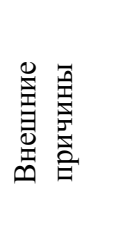 & 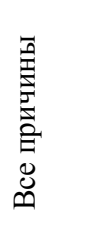 \\
\hline 0 & 71 & 5 & 6 & 139 & 7 & 659 & 83 & 970 \\
\hline $1-4$ & 21 & 17 & 3 & 58 & 2 & 75 & 109 & 284 \\
\hline 5-9 & 5 & 9 & 4 & 9 & 2 & 31 & 72 & 133 \\
\hline $10-14$ & 3 & 9 & 2 & 4 & 1 & 18 & 70 & 106 \\
\hline $15-19$ & 10 & 14 & 12 & 8 & 4 & 38 & 216 & 302 \\
\hline $20-24$ & 23 & 21 & 26 & 15 & 9 & 60 & 285 & 440 \\
\hline $25-29$ & 31 & 31 & 51 & 19 & 22 & 65 & 300 & 518 \\
\hline $30-34$ & 36 & 60 & 100 & 29 & 31 & 77 & 320 & 653 \\
\hline $35-39$ & 36 & 89 & 171 & 39 & 46 & 81 & 362 & 825 \\
\hline $40-44$ & 41 & 133 & 327 & 51 & 68 & 84 & 408 & 1112 \\
\hline $45-49$ & 35 & 191 & 613 & 73 & 83 & 107 & 466 & 1568 \\
\hline $50-54$ & 30 & 200 & 1117 & 73 & 109 & 119 & 504 & 2152 \\
\hline $55-59$ & 20 & 188 & 1981 & 71 & 162 & 124 & 506 & 3051 \\
\hline $60-64$ & 0 & 41 & 3065 & 43 & 122 & 44 & 380 & 3696 \\
\hline $65-70$ & -28 & -171 & 5182 & 30 & 102 & -72 & 312 & 5355 \\
\hline Всего & 333 & 837 & 12659 & 662 & 772 & 1510 & 4393 & 21165 \\
\hline Число избыто & x смертей & Бо. & 000 & 300 & 100 - & & Мен & \\
\hline
\end{tabular}

И у мужчин, и у женщин в возрасте до 45 лет вклад внешних причин в смертность выше, чем сердечно-сосудистых болезней.

Иванова: - Так и должно быть.

Вишневский: - Конечно, но достаточно ли это осознается? Сейчас у нас объявлен год борьбы с сердечно-сосудистыми заболеваниями. А будет ли год борьбы с внешними причинами смерти - c учетом их очень неприятного влияния на среднюю продолжительность жизни? Вообще, какими должны быть приоритеты политики, направленной на снижение смертности? Усиление контроля над какими причинами смертности важно в первую очередь?

Ермаков: - Ваша табличка и показывает.

Вишневский: - Мы впервые построили такие таблички с Владимиром Михайловичем 20 лет назад. Наши попытки показать это в Минздраве встретили сопротивление, они не захотели смотреть. Хозяин - барин. Соответствуют ли нынешние приоритеты в политике приоритетам, вытекающим из нашего анализа? Хочу обратить ваше внимание, что в наших таблицах относительно благополучно выглядит рак, избыточная смертность от него в возрастах до 70 лет относительно невелика, в возрасте 65-69 лет у нас есть даже преимущество. А в стратегии Минздрава борьба с онкологической смертностью занимает одно из первых мест.

Школьников: - По-моему, Анатолий Григорьевич, вы просто помогаете руководству страны переложить ответственность. Вы им говорите: главное - это травматизм, внешние 
причины. От них наибольшие потери лет человеческой жизни. Минздраву это на руку, поскольку за смертность от травматизма он отвечает только в небольшой части. Вы им говорите, что рак - это не главное. Дайте этот аргумент в руки политикам, и он будет восприниматься как оправдание дальнейшего урезания онкологической службы. На самом деле у нас недофинансировано большинство направлений. Тут и рак, и сердечнососудистые заболевания, и скорая помощь, и диабет, и многое-многое другое. В такой ситуации опасно говорить, что рак - это неважно.

Вишневский: - Я не говорю, что рак - это неважно, тем более, что у нас есть отставание и по раку. Я говорю о приоритетах. Онкологическими проблемами многие занимаются, к ним привлечено внимание, есть серьезные научные институты. А по внешним причинам, потери от которых не меньше, а наше отставание от других стран намного больше, ничего такого нет.

Ермаков: - Кстати, и статистика по раку достоверная. У нас ведь есть ассоциации Международная (Россия, Белоруссия, Украина) лига пациентов по борьбе с раком почки, Российское общество клинической онкологии, Ассоциация онкологов России, - есть канцер-регистры (государственный раковый регистр, популяционные регистры больных с злокачественными новообразованиями в субъектах РФ и госпитальные раковые регистрынапример, в Санкт-Петербурге, Самаре, Красноярске и др.), регистры по государственной программе «7 нозологий», включающей регистр больных миелолейкозом.

Иванова: - Тем не менее существуют сомнения в достоверности учета онкологической смертности, особенно в старших возрастах, в которых наиболее популярный диагноз хроническая ишемическая болезнь сердца неуточненная, который ставят, в том числе, и «на основании осмотра трупа». А при сокращении числа вскрытий посмертная постановка диагноза онкологического заболевания носит единичный характер.

Школьников: - Но все же с внешними причинами в смысле качества данных дело обстоит намного хуже. Алла Ефимовна как раз много сделала на эту тему. И Евгений Михайлович в последнее время выполнил серьезный анализ. У нас, как известно, очень выросла смертность от неустановленных неестественных причин, когда неизвестно, насильственные они или случайные. А здесь надо серьезно разбираться: отравление алкоголем - это одно дело, самоубийство - другое, а убийство - третье. Это все-таки три разные вещи, и нужно знать масштабы каждого из этих явлений. Сейчас у нас неточные представления об этом. Фиксируется огромный рост смертности от неустановленных причин в Москве и в ряде регионов. В конце советского времени на них приходилось всего что-то меньше 10\% смертности от всех неестественных причин. Сейчас эта причина на первом-втором месте в данном классе причин. Очень возможно, что за ростом смертности от неустановленных причин скрывается рост убийств и самоубийств. Есть много вердиктов судов, в которых показано, как человек А и человек Б распивали спиртное в течение 4 часов, а потом А на основе «возникшей неприязни» ударил Б по голове «тяжелым тупым предметом», что впоследствии привело к смерти Б. Но закодировать смерть от этого события можно по-разному.

Иванова: - Там важны намерения, потому что в качестве убийства этот случай не закодируют, если не было намерения убить. 
Ермаков: - Есть еще вопрос, насколько достоверна наша статистика причин смерти. Боюсь, по некоторым вещам мы не доберемся до истины никогда.

Приведу конкретный пример из своего опыта. На одной из территорий мы поставили систему ФАИСС-2 (Фактографическая автоматизированная информационно-справочная система, авторская разработка 1990 г.) для ввода и анализа свидетельств ЗАГС о смерти на уровне региона. Система на территории понравилась, они попросили, чтоб мы стали вводить также и персональные данные (тогда еще не было закона о персональных данных) - фамилию, имя и отчество, место жительство, даже улицу, дом, квартиру, - для того, чтобы Минздрав области мог послать врача, и он на месте разобрался, что там на самом деле произошло. Когда мы ввели данные, я решил посмотреть, что получается. В областном центре - 1,3 млн человек. Мне стало интересно, какие первоначальные причины смерти ставятся умершим в стационаре и подвергнутым патологоанатомическому вскрытию. Оказалось, что среди умерших, удовлетворяющих упомянутым условиям, очень много (десятки лиц) случаев, когда первоначальная причина смерти закодирована символом $\mathrm{R}$ это неточно обозначенные и прочие причины смерти. Я пришел к министру здравоохранения области, он вызвал заместителя по лечебной работе, дал бумажку с адресами таких умерших (только в областном центре) и сказал: «разбирайтесь!». Через год я его встречаю, он увиливает от встречи, но когда наконец мне удалось спросить его о результатах, он говорит: «Иди отсюда! Если обнародовать, то нужно нас всех стрелять». А мы каким-то записям о смерти собираемся верить или не верить. Статистика причин смерти даже в стационарах, даже в случае вскрытия существенно не достоверная.

Вишневский: - Если говорить обо всех внешних причинах в целом, то на общую смертность от них перераспределение внутри класса не влияет. Но с точки зрения приоритетов политики важно, конечно, и то, что происходит внутри класса. Я недавно участвовал в одном совещании, где представитель Минздрава долго рассказывал о том, как они борются со смертностью от ДТП. И мне показалось, что он был удивлен, когда я сказал, что ДТП это серьезная причина смерти, но на нее приходится только $10 \%$ смертей от внешних причин, и спросил, кто борется с остальными 90\%? Он промолчал.

Комаров: - Они и с ДТП неправильно борются, они борются приближением медицинской помощи к наиболее опасным местам возможного происшествия. Это неправильный подход. Посмотрите, как в Швеции. Надо дороги хорошие делать, обочины делать, улучшать работу полиции, деньги вкладывать.

Школьников: - В Москве, например, на развязках автодорог можно увидеть полосы разгона всего по 50 м длиной. Но, конечно, дело не только в ДТП. На смертность от внешних причин влияет такой серьезный фактор (скорее, это даже группа факторов), как «небезопасность жизни» (Human insecurity). Это наличие или отсутствие пожарных лестниц и выходов в высотных домах, это та или иная степень соблюдения технических требований и стандартов, это то или иное качество дорог и дорожной разметки, это различного рода предупредительные надписи, это то или иное качество работы спасателей и т.п., это защита газовых сетей, оборудования. Все эти вещи требуют очень большого внимания, и в России пытаются в этом наводить порядок. Кое-что заметно в Москве, но крайне недостаточно.

Вишневский: - До моего дома в Москве наведение порядка еще не дошло. Я живу в 16- 
этажном доме, у нас есть две пожарные лестницы во внешних нишах, и уже дано висит объявление, что на них выходить запрещено, потому что это опасно для жизни. Как нам объяснили, ремонтировать их чрезвычайно дорого, поэтому их, скорее всего, вообще снимут.

Понятно, что с точки зрения интересов разных ведомств - не только Минздрава лучше, чтобы статистика фиксировала больше смертей от таких причин, за которые никто не отвечает. Но это еще одно основание сказать, что нужен вневедомственный подход, комплексное изучение всего блока внешних причин смерти, и этим кто-то должен заниматься. Минздрав, видимо, не считает весь блок в целом зоной своей ответственности, МВД - тем более, и нет никаких научных центров, которые достаточно всесторонне изучали бы эту проблему, приобретающую все большее социальное звучание.

\section{СМЕРТНОСТЬ И АЛКОГОЛЬ}

Андреев: - Известно, что смертность от внешних причин сильно связана с алкоголем, но я хотел бы подчеркнуть, что и большинство смертей от болезней системы кровообращения в интервале возрастов от 35 до 60 лет - это следствие злоупотребления крепким алкоголем. Есть много статей на эту тему, хотя в каких-то конкретных случаях может быть это и не так.

Ермаков: - Владимир Михайлович, только что говорил совсем обратное: в его исследовании доказано, что сосуды у пьющих гораздо лучше устроены.

Школьников: - Нет-нет, это - разные вещи. Есть и другие виды сердечно-сосудистой патологии, например, такие, как кардиомиопатии, аритмии, фибрилляция предсердий.

Андреев: - Или просто пьяный инфаркт. Это давняя проблема. Есть исторические данные, доказывающие, что в России чрезвычайно высокая смертность от перепоя существует, по крайней мере, с 1865 г. Имеются данные дореволюционного Центрального статистического комитета, которые показывают, что проблема высокой смертности от алкогольных причин существует, по крайней мере, 150 лет. Еще в те годы смертность от алкогольного перепоя на территории современной Российской Федерации была в 6-7 раз выше, чем на Украине, Белоруссии, не говоря уже о балтийских губерниях, по сравнению с которыми она была в 16 раз выше. Не знаю наверняка, но возможно, дело в том, что в западной части Империи пили часто и помалу, а в России - редко, в основном на праздники, но в таком количестве, что от этого можно было умереть. И сейчас мы такие смерти классифицируем как смерти от инфаркта или инсульта. 
«Два слова об одном источнике резерва - о водке. Есть люди, которые думают, что можно строить социализм в белых перчатках. Это - грубейшая ошибка, товарищи. Ежели у нас нет займов, ежели мы бедны капиталами и если, кроме того, мы не можем пойти в кабалу к капиталистам, не можем принять тех кабальных условий, которые они нам предлагают и которые мы отвергли, - то остается одно: искать источников в других областях. Это всё-таки лучше, чем закабаление. Тут надо выбирать между кабалой и водкой, и люди, которые думают, что можно строить социализм в белых перчатках, жестоко ошибаются».

[Сталин 1952: 340].

Комаров: - Я когда-то работал на Украине, там человек приходит домой, берет бутылку водки, жена ему яичницу с салом, достает огурчики - помидорчики, и ни в одном глазу. Я переехал в Подмосковье, работал главным врачом в Раменской больнице - там рукавом закусывали; умирал человек, выпил и умирал; засыпал, а ночью шел дождь, и он захлебывался. Это кошмар.

Школьников: - Между серединой 80-х и в 90-е годы происходили большие колебания смертности примерно в одних и тех же возрастах от 15 до 60 лет, в основном симметричные, и связанные с алкоголем. Та же смертность от внешних причин в этих возрастах, несомненно, сильно связана с алкоголем, особенно когда речь идет о смертности от насилия. Алкоголь был важным фактором примерно 80\% убийств - так показало наше исследование в Ижевске в конце 90-х. Там было показано, для какого процента убийств в регионе преступник и/или жертва находились в сильном опьянении.

А потом стало происходить нечто другое. Далеко не все изменения смертности в 2000-е связаны с алкоголем, значительная часть изменений была связана с алкоголем, но не всё.

Вишневский: - Так говорится, но доказательности в этом не может быть.

Школьников: - В этом нет абсолютной доказательности, поскольку нет подтверждений на уровне микроданных.

Ермаков: - В 1985 г. был совместный проект по снижению смертности от болезней системы кровообращения в Финляндии и Карелии. Я даже участвовал в совещаниях по этому проекту. Так вот, с 1986 г. за 20 лет финны снизили на 80\% смертность свою от болезней системы кровообращения, а мы? У нас ничего не изменилось. Почему?

Школьников: - Нет, я совершенно не согласен, что ничего не изменилось.

Ермаков: - Но финны же снизили на 80\%. В пять раз снизили смертность, а мы ее практически не снизили!

Школьников: - Потому что они лучше работают, а наше здравоохранение (в широком смысле слова) сработало намного слабее. Однако все-таки многое сделано. Об этом говорит характер снижения смертности в 2005-2014 гг.

Ермаков: - Если убрать первую, правильную, часть вашего утверждения (они лучше 
работают), то во второй имеется существенная неточность - мы не просто работаем слабее, мы ничего не делаем, если сравнивать масштаб и качество проведенных лечебнопрофилактических мероприятий. Мы - это не мы с вами.

Вишневский: - В свое время, по Финляндии во всяком случае, была статистика, впрочем, не только по Финляндии, что за это время очень сильно изменилась структура алкогольного потребления.

Школьников: - У нас она тоже меняется, кстати, сейчас.

Вишневский: - Все говорят, что меняется, и я тоже так думаю, но серьезных доказательств нет.

Немщов: - Сейчас уже есть. Появилось несколько превосходных работ, выпущенных Высшей школой экономики, Российской экономической школой, Институтом имени Гайдара. Можно считать доказанным, что по мере омоложения потребителей происходит прогредиентное увеличение в потреблении доли пива и уменьшение доли водки. Последнее особенно отчетливо проявляется после 40 лет.

Школьников: - В РМЭЗ есть хорошие доказательства, есть данные, что структура потребления алкоголя меняется в разрезе поколений. Евгений Михайлович Андреев эти данные анализировал. Есть подтверждение, что в потреблении молодых поколений гораздо выше доля пива. При этом старшие поколения свои предпочтения модифицируют мало и продолжают потреблять водку. А для пива, как известно (хотя кричат по радио и по телевизору, что пиво - это страшная опасность), нет ни одной научной статьи, которая связала бы его потребление со смертностью.

Немщов: - Точнее, нет ни одной смерти, связанной с острым отравлением пивом. В связи с пивом умирают, но редко и обязательно при мощном злоупотреблении. Причиной бывает «пивное» сердце или «пивные» почки. Однако связано это не столько с алкоголем пива или с его сухим остатком, сколько с нагрузкой организма водой, которая составляет более $90 \%$ пива. Я всячески поддерживаю переход с крепких напитков на пиво и вино как выбор из двух зол меньшего. Однако вино никогда не будет в России распространенным напитком из-за нашего климата и дороговизны этого напитка. Остается пиво в качестве главного напитка, способного потеснить водку. К сожалению, алкогольная политика нашего государства определяется не рациональными мотивами оздоровления населения, а совсем другими мотивами и более всего клановыми предпочтениями.

Вишневский: - Мы очень давно говорим, что главное направление алкогольной политики это именно изменения в структуре потребления, а не сухой закон. Но вы знаете позицию нашего главного санитарного врача (до недавнего времени) - если верить ему, да и некоторым другим, нас просто затопило пивом. 
«Анализ структуры продажи алкогольной продукции свидетельствует, что впереди всего пиво: 80 процентов. Доля водки и ликероводочных изделий составляет 13 процентов, 6 процентов приходится на вино и 1 процент на коньяк. К сожалению, полностью оправдался прогноз медиков 2000 года, когда они выступали против преступной, ориентированной на молодежную аудиторию пропаганды пива, когда доказывали, что это не приведет к изменению в структуре потребления спиртного. На фоне увеличения производства слабых алкогольных напитков и особенно пива значительно выросло потребление тяжелого алкоголя. Более всего опасны внедряющиеся в жизнь молодых россиян энергетические напитки, сочетающие алкоголь с тонизирующими веществами, которые усиливают вредоносное действие алкоголя на организм».

[Онищенко, 2009].

Понимал ли Г. Онищенко, что он сравнивает потребление водки и пива не в пересчете на чистый алкоголь, а в декалитрах жидкости, которая опасна не сама по себе, а в зависимости от содержания в ней главного и почти единственного токсического агента этилового спирта? Понимал или не понимал, но получалась страшная картина, когда надо бороться с пивом, больше чем с водкой. Он и боролся.

Немщов: - И боролся не даром. Сейчас есть подозрения, что его активность подогревалась коррупционной составляющей. Давайте, я все-таки скажу про эту ситуацию. Снижение потребления, которое произошло после 2003 г., в значительной степени связано с изменением потребления, главным образом, в молодых возрастах. Важно отметить, что молодые возраста - это не только подростки и молодежь, изменение начинается с нынешних 50-летних, которые родились в 1960-е. Нарастание идет в направлении все большего потребления пива, и чем моложе потребители, тем большая доля пива в их потреблении. Началось это с 1998 г., когда пришли к нам в страну крупные зарубежные компании, появилось мощное производство сравнительно неплохого пива и люди начали переходить с водки на пиво. Этот процесс шел особенно быстро в городах. Так происходило во всем мире, только во всем мире это началось гораздо раньше. Когда в 1982 г. ВОЗ призвала правительства всех стран переориентировать население на слабые алкогольные напитки, вино и пиво, в развитых странах уже шло изменение структуры потребления в этом направлении. Это был процесс, вызванный в Европе и Америке в послевоенную пору изменением стереотипа жизни, нарастанием мобильности, ростом ценности здоровья. Всему этому сильно мешали крепкие напитки, и население этих стран спонтанно стало отдавать предпочтение пиву.

Вишневский: - То есть у нас происходило то же, что у наших соседей, например, в Финляндии и, кстати, в Польше, где тоже резко изменилась структура потребления?

Немиов: - Да, то же, только у нас это началось позже. Это был процесс, связанный, как и на Западе, с изменением социальных условий жизни. Пить крепкий напиток стало неудобно. Гораздо легче бутылка-банка пива, закуска и пошел обратно на работу.

Может быть не странно, что этот сдвиг в сторону пива происходит даже в винодельческих странах. Там тоже начинают потреблять все больше пива. Это общая 
тенденция, связанная, возможно, с тем, что в потреблении вина больше символической составляющей, чем в пиве. Кроме того, пиво по алкоголю в целом слабее вина. Мне кажется важным поддержать политически эту тенденцию вслед за населением: выбор из двух зол (водка - пиво) меньшего, то есть пива.

Вишневский: - Мы бы с радостью опубликовали работы, о которых вы упоминаете. Лично я полностью согласен и с тем, что вы сказали, и с тем, что сказал Владимир Михайлович, только у меня нет доказательств. Если они у вас есть, давайте опубликуем.

Школьников: - Есть объективные данные, уже появились сейчас.

Вишневский: - Кроме того, есть вопрос о том, насколько изменения, о которых вы говорите, связаны со смертностью. Очень возможно, что это так, но тоже, наверное, нужны отдельные доказательства, в том числе и по возрастным группам.

Немщов: - В последние годы изменилась возрастная структура смертности: она сдвигается на старшие возраста, по-видимому, и отчасти за счет того, что молодые стали употреблять более легкие напитки.

Вишневский: - Я тоже хотел бы так думать, мне кажется, что так именно и должно быть. Это разумный путь, он уже проделан многими странами. А появление пива как материального вещества, некогда весьма дефицитного, должно было бы этому способствовать. Есть такое стихотворение поэта Бориса Рыжего, воспоминание о его советской молодости, о том, «как хорошо мы плохо жили»:

\section{В те незабвенные года \\ Нам пиво воздух заменяло, Оно внезапно исчезало \\ И появлялось иногда.}

Сейчас оно никуда не исчезает, есть качественное пиво, поэтому естественно ожидать, что оно немного потеснит водку. Но тут многое зависит от ценовой политики, которая у нас тоже неправильная: поднимают цены на пиво, а опускают - на водку. Должно было бы быть наоборот.

Немщов: - Да, удешевление пива, даже небольшое, было бы одним из способов перевода населения на слабый алкоголь.

Вишневский: - Но давайте теперь, может быть, поставим вопрос более широко: что вообще повинно в российском отставании: условия жизни, образ жизни, отсутствие четкой государственной политики охраны здоровья, плохая работа системы здравоохранения, чтото еще? Ответы на этот вопрос будут, скорее, субъективными, но все-таки: как вам кажется?

\section{НИЗКАЯ ЭФФЕКТИВНОСТЬ ЗДРАВООХРАНЕНИЯ}

Комаров: - Давайте экспертно решим. На первом месте - отсутствие последовательной государственной политики, это без вопросов.

Школьников, Ермаков: - Согласны. 
Шишкин: - Нет, не соглашусь, деклараций у нас с избытком хватает.

Комаров: - Это не политика.

Шишкин: - Это часть политики. Если вы скажите, что политика отсутствует, то вам тут же ответят, что мы вот такой документ приняли и вот такой. И что вы их, видимо, не читали.

Андреев: - В 70-е годы известный американский ученый Самуэль Престон придумал кривую, которая устанавливает связь между ожидаемой продолжительностью жизни и ВВП [Preston 1975: 231-248].

Школьников: - Это логарифмическая кривая с насыщением.

Андреев: - Да. Эту кривую формально можно строить по любым данным. Если взять страны, которые реально рассчитывают продолжительностью жизни, и не брать Кувейт, ОАЭ, Китай и т.д., где сомнительная статистика. Таких стран около $30 \ldots$

Школьников: От 30 до 40.

Андреев: - Так вот, если взять эти страны и построить кривую Престона, то оказывается, что продолжительность жизни в России на восемь лет ниже, чем предсказывает формула Престона.

Ермаков: - Это совершенно верно. Я могу вам показать эту кривую - у меня получается, что мы отстаем от остальных европейских стран на 10 лет по кривой Престона. Посмотрите на график (рисунок 10), здесь по оси $\boldsymbol{x}$ - общие затраты на здравоохранение по паритету покупательной способности на душу населения, а по оси $\boldsymbol{y}$ - величина ожидаемой продолжительности жизни при рождении. На графике представлены все европейские страны по выделенным подгруппам. Зеленым цветом обозначены бывшие советские республики, синим - бывшие соцстраны, а желтым - все остальные европейские страны. Заметим, что если объединить эти три группы стран, то все они ложатся на общую кривую Престона, что иллюстрирует общую для всех этих стран закономерность. А для России (она обозначена красными кружками) закономерность совсем другая! Если продолжить обе эти кривые, то можно видеть, что даже если мы увеличим общие затраты на здравоохранение в 2-5 раз, то наше отставание от европейских стран по величине ожидаемой продолжительности жизни не сократится, а останется в пределах 10 лет. Из приведенного графика можно сделать предварительный вывод о наличии системных ошибок в руководстве российской системы охраны здоровья населения. 


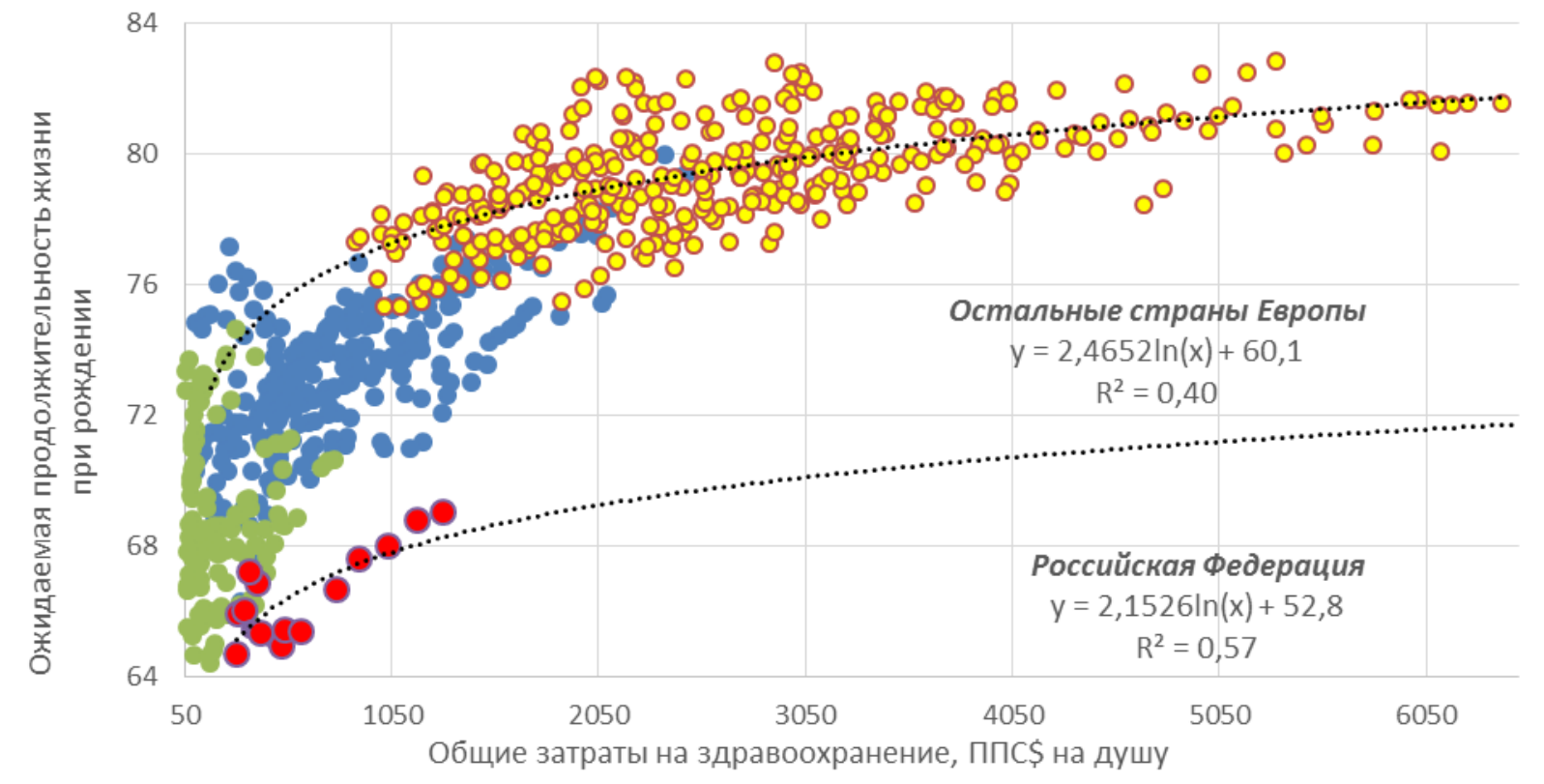

\section{Рисунок 10. Связь между продолжительностью жизни и затратами на здравоохранение}

Школьников: - Другими словами, у нас ВВП далеко не такой низкий, но маленькая доля этого ВВП идет на здоровье.

Вишневский: - Но я так понял, что на графике Сергея Петровича представлены как раз затраты на здоровье, и мы им не соответствуем.

Ермаков: - По картинке с кривой Престона видно: в три раза увеличилось финансирование, а все равно ничего не изменилось.

Школьников: - Иными словами, у нас продолжительность жизни ниже, чем можно было бы ожидать, исходя из уровня нашего экономического благосостояния.

Комаров: - Из этого власть, видимо, и делает выводы о том, что мы вполне можем улучшить здоровье населения даже при наших экономических возможностях.

Андреев: - Я не знаю, что думает власть, но, по-моему, из этого следует, что наша политика в сфере здоровья совершенно неэффективна.

Шишкин: - Об этом и надо говорить, о неэффективности, а не об отсутствии политики. О неэффективности политики.

Андреев: - Недавно некий журналист почти довёл меня до сумасшествия, убеждая, что здравоохранение отвечает за 10-15\% уровня здоровья. Совершенно неожиданно узнал из лекции Школьникова, что он тоже встречался с этим утверждением.

Школьников: - Да-да, есть такая популярная точка зрения. Откуда это идет?

Комаров: - Это из работ $60-$ х годов.

Шишкин: - Я пытался это выяснить, сидел в западной библиотеке, искал ссылки. Нашел работу 1978 г., на которую все ссылались, там нет никаких эмпирических данных, нет ссылок - просто экспертное мнение. И потом все на него стали ссылаться.

Комаров: - Так вот получается. Не отсутствие четкой государственной политики, а отсутствие эффективной государственной политики - видимо, так надо сформулировать. 
Вишневский: - В рейтинге агентства Блумберг, на который сослался Путин, на самом деле приведено 4 рейтинга. Помимо рейтинга по продолжительности жизни, есть еще рейтинги по доле ВВП, расходуемой на здравоохранение, и по абсолютным затратам в долларах по паритету покупательной способности. По этим двум показателям мы не на 51-м месте, а все-таки выше, где-то на 30-35-м. Это как раз и говорит о неэффективности, ведь, казалось бы, мы могли быть хотя бы на 35-м месте и по продолжительности жизни. Это все же лучше, чем на 51-ом.

Школьников: - Именно. Есть много более бедных стран, которые имеют более высокую продолжительность жизни, чем мы.

Вишневский: - Или имеют худшую статистику смертности.

Комаров: - Вы подтвердили то, что сказал Евгений Михайлович. Видимо, надо все-таки говорить не об отсутствии государственной политики, а об ее неэффективности

Вишневский: - Я согласен с тем, что деньги, которыми располагает система здравоохранения, тратятся неэффективно. Но это не значит, что денег у нас достаточно. Самая высокая доля затрат на здравоохранение в ВВП у нас была достигнута в 2009 г., потом она снова стала снижаться. Стоимость медицинских услуг на душу населения в России в 2014 г., по оценке того же Блумберга, меньше 900 долларов в год, в Японии - 4,8 тыс. долларов, а в Норвегии больше 9 тыс.

Когда денег мало, особенно важны приоритеты их использования. Есть такое понятие: гонка медицинских вооружений. Когда говорят о высокотехнологических методах, а люди гибнут, не дойдя до врача.

Комаров: - Потому что это выгодно. Это большие откаты.

Вишневский: - Это просто еще один элемент неэффективности.

Иванова: - Есть очень сильный неудовлетворённый спрос на высокотехнологическую помощь.

Комаров: - Есть, а знаете почему? Потому что плохо работают все остальные звенья. Чем они хуже будут работать, тем больше будут продуцировать хронизацию патологий, более тяжелые случаи заболеваний, и так далее. И чем больше будет всего, тем больше будет потребность в дорогостоящих высоких технологиях.

Школьников: - Это совсем не означает, что высокотехнологические методы не нужны.

Вишневский: - Я думаю, никто здесь не считает, что высокие технологии не нужны. Но все хорошо в меру. Огромное количество людей, молодых мужчин, которые умирают у нас от внешних причин, да и от многих других, - они же умирают не из-за того, что нет медицинских технологий. Кроме того, дорогостоящее высокотехнологичное оборудование поглощает значительную часть затрат, а так как денег мало, то кому-то достаются только крохи с барского стола, у кого-то нет доступа даже к элементарной медицинской помощи. Медицинские технологии нужны для определенных возрастов, для определенных патологий. Но во многих случаях люди умирают от рядовых причин, просто потому, что вовремя не получили помощи врача или врач был недостаточно квалифицированным. Вообще самая высокая медицинская технология - это хороший врач. 


\section{СИСТЕМА БЕЗ ОБРАТНОЙ СВЯЗИ}

Немщов: - Я согласен с тезисом Сергея Владимировича о том, что политические декларации - тоже политика в смысле создания иллюзии политической деятельности, маскировки политической бездеятельности. Руководство страны все время старается показать, что оно что-то делает. Дума издает странные законы. Правда, в такой бездеятельности часто просматриваются чьи-то интересы.

Но вот что бы я хотел сказать более серьезно. Как вы относитесь к тому, что в число обстоятельств, повинных в российском отставании, надо записать еще особенности ментальности русского народа, который наплевательски всегда относился к своему здоровью и к своей продолжительности жизни, вследствие чего и сейчас преждевременная смерть человека воспринимается как смерть естественная - ну как же, пил человек или перетрудился на работе?

Школьников: - Многие вам скажут: это пренебрежение человеческой жизнью и т.П., что всегда было характерно для России. Но ведь такое же пренебрежение было и в странах Балтии, которые сейчас от нас оторвались, как известно, например, в Эстонии. Что делается в Эстонии? Надо бы взять, да и сделать все то же самое, и будет успех и у нас, я вас уверяю. Как раз успех последних лет показывает, что Россия - это не черная дыра, где, что ни делай, ничего не получится, а как раз он показывает, если делать то, что нужно, то все получится и даже лучше, потому что у нас запас «дурости», на которой основана высокая смертность, намного больше, чем в других местах. Поэтому начало ликвидации этой дурости обязательно приведет к особенно быстрому сокращению смертности. Она у нас и сейчас сокращается, хотя у нас не хватает доказательной базы в отношении причин улучшения.

Ермаков: - Я маленькую реплику вставлю по поводу того, что вы сейчас говорите. На самом деле, есть устойчивая причина некоторого роста ожидаемой продолжительности жизни. Это начало «сытых годов» с 2003 г. Людям стали больше платить зарплату, они получили возможность более качественно питаться, куда-то поехать.

Школьников: - И лекарства современные стали покупать и использовать.

Ермаков: - Естественно, национальный проект «Здоровье», хоть он не был непосредственно направлен на улучшение показателей здоровья, поэтому и мониторинга по нему не было. Но ведь основные фонды, особенно высокотехнологичное оборудование, скорая помощь - они были в ужасающем состоянии, и если бы в них не вложить достаточно большие деньги, то ничего бы и не произошло. Вот эти две причины - они устойчивы, а все остальное - это потом.

Школьников: - А что касается ментальности, так финский народ тоже много пил, бедная страна была. Тоже страшное прошлое - голод 1867-68 гг., 20\% населения тогда вымерло. Еще в 1970-е годы у них смертность такая же, как в России, была.

Ермаков: - Но они с ней эффективно боролись. Приведу только один пример - как они снизили число самоубийств.

Национальная стратегия по предупреждению самоубийств в Финляндии (1986-1996 гг.) была реализована по уровням местного, регионального и национального применения. 
Стратегия затрагивала государственную систему образования и была направлена на улучшение доступа к службам охраны психического здоровья, реализацию помощи в кризисных ситуациях, сокращение доступа к средствам самоубийства, повышение информированности медицинских работников о факторах и условиях стремления к самоубийствам, сопутствующей заболеваемости, мониторингу попыток самоубийств. Реализация стратегии привела к созданию более 40 подпрограмм и других инновационных разработок и оценивалась через внутренний оценочный процесс и общенациональный опрос. В результате проведения такой оценки было признано, что программа была успешной.

Примерно в это же время сходные программы стали реализовываться и в других странах мира (рисунок 11)

\begin{tabular}{|c|c|c|}
\hline \multicolumn{2}{|c|}{$\begin{array}{l}\text { NATIONAL SUICIDE PREVENTION STRATEGIES } \\
\text { Graham Martin 0AM, MD, FRANZCP, DPM \& Andrew Page, PHD, The University of Queensland }\end{array}$} & $\begin{array}{l}\text { Facing the Challenges, Buildin } \\
\text { Helyink, Finlend 12-15 January 2005 }\end{array}$ \\
\hline \multicolumn{3}{|l|}{ Finland, 1992} \\
\hline Norway, 1994 & \multicolumn{2}{|c|}{10 key items in suicide prevention in Finland } \\
\hline Australia, 1995 & \multirow{2}{*}{\multicolumn{2}{|c|}{$\begin{array}{l}\text { The National insuitute for Health and Welfare recently updated its guidelines for suicide prevention. These } \\
\text { guidelines include a list of } 10 \text { key items in suidide prevention. }\end{array}$}} \\
\hline Sweden, 1997 & & \\
\hline New Zealand, 1998 & \multicolumn{2}{|c|}{ 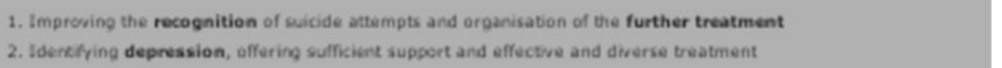 } \\
\hline France, 2000 & \multicolumn{2}{|c|}{$\begin{array}{l}\text { 3. During sprngtime heightened capacity for ibenofiving dupression and providing further treatment } \\
\text { 4. Imensifyng the prewention of alcohol and drugs use }\end{array}$} \\
\hline United States, 2001 & \multicolumn{2}{|c|}{ 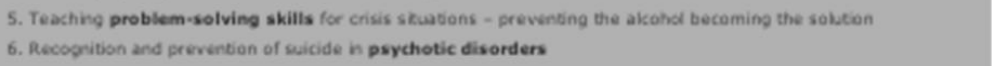 } \\
\hline England and Wales, 2002 & \multicolumn{2}{|c|}{$\begin{array}{l}\text { 7. Adsing psychical and social support to treating shysical disorters and ifnesies } \\
\text { 8. asting paychical and rocial support to people in crisis situations }\end{array}$} \\
\hline Scotland, 2002 & \multirow{2}{*}{\multicolumn{2}{|c|}{ 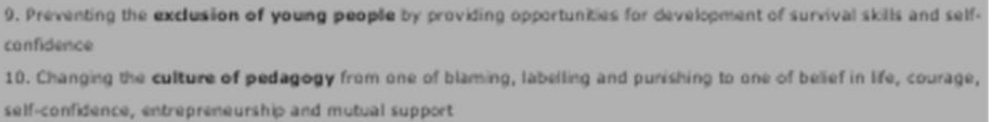 }} \\
\hline Japan 2000 & & \\
\hline
\end{tabular}

Рисунок 11. Реализация программ по предупреждению самоубийств в разных странах мира

И вот что получилось! Давайте сравним, на сколько снизились уровни самоубийств в России и в Финляндии (таблица 4). Все понятно?

Таблица 4. Смертность от самоубийств в России и Финляндии, 1990, 1995 и 2010 г.

\begin{tabular}{|c|c|c|c|c|c|c|}
\hline & \multicolumn{3}{|c|}{$\begin{array}{c}\text { Уровень самоубийств } \\
\text { (на } 100 \text { тыс. населения) }\end{array}$} & \multicolumn{3}{|c|}{$\begin{array}{c}\text { \% изменения смертности } \\
\text { (по периодам) }\end{array}$} \\
\hline & 1990 & 1995 & 2010 & $1995 / 1990$ & $2010 / 1995$ & $2010 / 1990$ \\
\hline \multicolumn{7}{|c|}{ Все возраста } \\
\hline Финляндия & 29,3 & 25,87 & 17,95 & $-11,7$ & $-30,6$ & $-38,7$ \\
\hline Россия & 30,84 & 51,48 & $\begin{array}{l}27,45 \\
15-4\end{array}$ & 66,9 & $-46,7$ & $-11,0$ \\
\hline Финляндия & 41,64 & 37,05 & 23,9 & $-11,0$ & $-35,5$ & $-42,6$ \\
\hline Россия & 37,4 & 67,34 & 34,27 & 80,1 & $-49,1$ & $-8,4$ \\
\hline
\end{tabular}


Немц̧ов: - В Финляндии существенно и быстро перестроилось образование. Почему они смогли организовать так давно и такую замечательную фирму как Nokia? Это же продукт культуры.

Школьников: - На культуру можно воздействовать.

Комаров: - Это зависит от политики.

Шишкин: - Знаете ли, это взаимный процесс. Сформировать привычку ходить к врачу можно массовой пропагандой, но одно дело, если вы пойдете к финскому врачу, где вас с радостью встретят и проведут по чистым кабинетам. Другое дело, вы пойдете записываться на прием в нашу поликлинику. У вас желание лечиться быстро исчезнет.

Немиов: - Ну, это частность. Вы знаете, как образно выразился писатель Федор Абрамов (из так называемых «деревенщиков»): американец пойдет к врачу за пять лет до появления заболевания, а русский обратится к врачу за пять минут до смерти.

Шишкин: - Я не спорю, можно воздействовать и на эти культурные стереотипы, но должна быть благоприятная, как мы говорим, пациенто-ориетированная система здравоохранения. А у нас она на себя работает.

Немщов: Я бы сказал шире - должна быть человеко-ориентированная политика.

Вишневский: - Александр Викентьевич вспомнил Федора Абрамова, мне тоже вспомнилось, как этот писатель, кажется, в каком-то интервью, рассказывал о стиле руководства секретаря Ленинградского обкома Толстикова. К нему приходили писатели, он объяснял им, как им надо писать; приходили врачи - объяснял, как нужно лечить, инженерам - как надо конструировать самолеты и так далее.

Мне кажется, что на основе такого «вертикального» мышления сейчас действует вся наша система здравоохранения. В ней нет главного, что должна иметь всякая система. Совершенно не действуют механизмы самоорганизации, нет внутренних поисков лучших вариантов, их нет на низовом уровне, все регулируется сверху. Насколько я могу судить, на Западе эта система довольно гибкая, она приспосабливается к меняющимся условиям: и население перестраивается, и медицина перестраивается, и врачи, и фармацевтика - все перестраивается, ведя самостоятельный поиск и адаптируясь к меняющимся условиям. А в нашей системе что-то вроде одного невидимого секретаря обкома на всю страну, и он один знает, как должно быть. Но даже и это, возможно, иллюзия. Я, конечно, не знаю работу этой системы изнутри, но, насколько можно судить извне, она очень инерционна. Там и министр ничего не может изменить, потому что такая вертикаль сложилась, она любого министра сжует. А уж тем более врач ничего не может, главврач ничего не может, свободы никакой нет.

Я не идеализирую западное здравоохранение, оно тоже далеко не всегда эффективно. Скажем, американская система очень дорогая, это известно. Они расходуют на здравоохранение огромную долю ВВП, нам такая даже и не снилась, и ВВП на душу населения у них не маленький, как вы понимаете. Но в том же рейтинге агентства Блумберг, о котором уже говорилось, по доле ВВП они занимают первое место, а по продолжительности жизни - только 24-е. Так что эффективность тоже не самая высокая. 
Но коль скоро мы говорим о нашем отставании и о том, как его преодолеть, мы должны искать в западных системах здравоохранения не нагатив, а позитив. Мы ведь отстаем от них по результатам, а это - самое главное. Я думаю, важно то, что там большую роль играют обратные связи, затраты лучше контролируются результатом. Если пациента не устраивает врач, он ищет другого, а врач ищет, что предложить пациенту, и так далее. Это относится и к клиникам, и к частным врачам.

Немцов: - Так как, по-вашему, называется главная беда нашего здравоохранения, как её назвать?

Вишневский: - Я думаю, что она как раз и заключается в отсутствии механизма обратной связи, в независимости затрат от результата и результата от затрат.

Андреев: - Ну, попросту, я бы сказал, отсутствие конкуренции. Я наблюдал систему здравоохранения в Германии. Там идет постоянная борьба между страховой компанией, которая стремиться сэкономить деньги, и врачом, который стремится получить деньги. Страховые компании платят бонус пациентам за то, что они вовремя лечат свои зубы, регулярно ходят к врачу и не доводят дело до экстренной госпитализации.

Комаров: - У нас конкуренции не может быть совсем, мы не Германия. Возьмем одну землю в Германии - Северный Рейн-Вестфалия. Там 498 крупных городов, у нас на всю страну - 164, причем при их сети дорог за 4 часа можно проехать всю Германию из конца в конец. Это совсем другой мир, там можно организовать конкуренцию. А у нас ее негде организовывать, даже в Москве сейчас нельзя организовать конкуренцию, потому что для конкуренции нужно рассредоточение, а мы создали монстров, укрупнили все, что можно было. С кем конкуренция, если нет врача в сельской местности?

Школьников: - Мне кажется, нужно идти от конца, так, по крайней мере, всегда говорит Мартин Макки, один из ведущих в мире специалистов в области общественного здоровья. Модели здравоохранения могут быть разными. Но каждая из них может решать проблемы борьбы со смертностью. Вот Анатолий Григорьевич говорит, что нужна конкуренция, нужно больше свободы экономической в здравоохранении. Экономисты строят модели здравоохранения. Но есть же Куба, есть штат Керала в Индии, - бедные страны и регионы с высокой продолжительностью жизни. Есть американская система, где все частное, но есть и английская система общественного здравоохранения, которая похожа на советскую модель. Есть континентальная европейская система типа французской или немецкой. И все они как-то решают проблемы. Проблемы можно решать по-разному, но надо решать - вот в чем вопрос.

Вишневский: - Вопрос в том, как решать. И как избежать ошибок. Я сейчас говорил о том, что одни и те же деньги можно тратить по-разному, а если нет обратной связи между затратами и результатом, так нет и эффективности. А как она может быть, если не умеют измерять результат, если о нем судят по общему коэффициенту смертности и на этом основании невежественные люди принимают решения?

Ермаков: - Скворцова однажды как-то Путину сказала, в первый раз, когда в России на несколько тысяч человек родилось больше, чем умерло за год: «ура! у нас преодоление депопуляции». 
Немизов: - Тогда же она сказала, что потребление алкоголя за пять лет снизилось на 4,4 литра. А такого быть не может: за три года антиалкогольной кампании при массивном прессинге снижение составило всего 3,5 литра.

Вишневский: - Что в итоге мы можем сказать о причинах нашего отставания? Мы ведь не принимаем резолюцию, тут, скорее, важны разные точки зрения. Я не думаю, что ссылки на какой-то особый менталитет русского народа, которые появляются всякий раз, когда надо объяснить что-то трудно объяснимое, что-либо в действительности объясняют. Дело не о народе, а в обществе: как организовано общество, как функционируют его институты, как оно распределяет свои ресурсы. Наше отставание как раз и говорит, что здесь у нас не все в порядке. Но как исправить положение? Способна ли наша система здравоохранения переломить ситуацию, нуждается ли она в реформировании и поддается ли она реформированию?

\section{ЧТО ДЕЛАТЬ?}

Комаров: - Мы в рамках Комитета гражданских инициатив Кудрина подготовили стратегию охраны здоровья [Основные положения...]. Как должно быть - и с точки зрения пациентов, и с точки зрения врачей, - чтобы плохо не было ни тем, ни другим. Подготовили такую стратегию, обсудили уже в Государственной Думе, прочитало её в Интернете 160 тыс. человек, никаких возражений нет. Сейчас я надеюсь, честно скажу, рассчитываю на нее, на предстоящие Общероссийский гражданский форум и Пироговский съезд врачей, где будут обсуждаться пути выхода из кризиса. Кстати этот вопрос поднимался и на всех предшествующих Пироговских съездах врачей.

Школьников: - А в чем главные идеи изменений?

Комаров: - Первая идея в том, что, во-первых, нужно отделить у нас в стране систему охраны здоровья от медицинской помощи, как в Конституции. В Конституции это четко записано: охрана здоровья и медицинская помощь (в 41-й статье).

Что такое охрана здоровья? Ее главная цель - улучшение здоровья населения. За охрану здоровья должно отвечать первое лицо государства - это Президент. За все, что влияет на здоровье: это бедность и здоровье, это условие труда и здоровье, питание и здоровье, окружающая среда и здоровье - там все формируется, все патологии, которые к нам поступают в медицину на восстановительные работы. Мы - ремонтновосстановительная бригада. Мы восстанавливаем утраченное здоровье. За организацию медицинской помощи должна отвечать отрасль. Ее главная цель - это восстановление утраченного здоровья и трудоспособности по медицинским показаниям.

Что надо делать в медицине в части организации медицинской помощи? Первое, нужно сделать акцент на предупреждении, но здесь мы может идти только медицинскими путями. То, что определяет образ жизни, зависит не от одного Минздрава, все предпосылки того или иного образа жизни всегда создает государство в широком смысле. Возьмем, скажем, простую вещь, допустим соль. Минздрав рекомендует потреблять 8 г соли в сутки, но даже, если мы смотивируем людей, чтобы они не подсаливали пищу, то 17 г добавляет 
государство: соль в хлебе, соль в масле, соль в колбасах, соль везде есть как консервант, понимаете. От государственной политики никуда не денешься. Мы можем мотивировать людей на здоровый образ жизни, но условия для ведения здорового образа жизни должно создать государство. Это в рамках первого направления, медицинской профилактики.

\section{Статья 41.}

1. Каждый имеет право на охрану здоровья и медицинскую помощь. Медицинская помощь в государственных и муниципальных учреждениях здравоохранения оказывается гражданам бесплатно за счет средств соответствующего бюджета, страховых взносов, других поступлений.

2. В Российской Федерации финансируются федеральные программы охраны и укрепления здоровья населения, принимаются меры по развитию государственной, муниципальной, частной систем здравоохранения, поощряется деятельность, способствующая укреплению здоровья человека, развитию физической культуры и спорта, экологическому и санитарноэпидемиологическому благополучию.

3. Сокрытие должностными лицами фактов и обстоятельств, создающих угрозу для жизни и здоровья людей, влечет за собой ответственность в соответствии с федеральным законом.

Конституциия Российской Федерациии

Второе, что нужно сделать, - акцент на первичную медико-санитарную помощь. Первичная медико-санитарная помощь - это более широкое понятие, чем просто еще один врач, ведущий прием. Primary Health Care - это первичная забота о здоровье, что вносит совсем иной смысл в содержание работы и в работу с пациентами. Это не врач общей практики, который, в нашем понимании, сидит и ведет прием, принимает больных. Не нужен такой врач. Во всем мире - это синдромальный врач. Наш Минздрав разрабатывает стандарты для первичной медико-санитарной помощи, например, онкологические стандарты: рак такой-то, 4 степени. Но ведь не придет же больной и не скажет: у меня язвенная болезнь или у меня рак. Он придет и скажет: что я ни поем - у меня боли ночью, у меня голодные ночные боли, пациент приходит с симптомами и синдромами - ему нужен синдромальный врач. Если вы возьмете классификацию Всемирной организации семейных врачей (WONCA), то вы увидите, что там указываются синдромы: боль в спине, например, изжога, головная боль. Нужен синдромальный врач, и он должен заниматься лечением малую долю времени. Потому что, кроме врача этого первичного звена, больше никто не скажет, какая патология у него идет на участке. И только он может сказать органам власти: вы знаете, я смотрю, что у нас что-то неблагополучно с кишечными заболеваниями. Решить это вопрос он не может, но поднять вопрос перед органами власти обязан. Потому что другого нет человека, нет такого органа, который мог бы поставить вопрос перед органами власти. Вот что такое первичная медико-санитарная помощь.

Структура здравоохранения должна быть такая: помощь общего типа максимально приближена к населению, а помощь специализированная может быть на расстоянии. Это вообще принцип градостроительства, потому что все должно быть рядом: магазины рядом, булочная рядом, молочная рядом, школа начальная должна быть рядом, чтобы школьник 
не переходил через улицу. А все остальное может быть в отдалении, на расстоянии. Все что касается общего типа должно быть рядом, а специализированная помощь может быть на расстоянии. В нашей программе подробно все расписано, как что должно быть, я просто грубо говорю.

Немиов: - А каковы условия для реализации вашей программы?

Комаров: - Там все расписано, все можно прочитать.

Немцов: - И реальные условия для реализации?

Комаров: - Да, реальные. На первом этапе деньги дополнительные не нужны. Потому что мы сейчас тратим не туда, да еще и воруем, а в действительности их достаточно, если правильно использовать.

Вишневский: - Но все-таки важно понять механизм. Где-нибудь во Франции или Германии я знаю, что вот эта лаборатория, как и магазин, и что угодно, это инициатива того, кто её создал. Он нашел место подходящее, он первый, кто заинтересован в том, чтобы быть ближе к пациенту. У нас решение принимают мэр, муниципальные чиновники...

Комаров: - Это все должно быть по закону.

Вишневский: - Законы есть везде, но работают по-разному.

Комаров: - Про наши законы я сам кое-что могу рассказать. Вот, например, 323-й Федеральный закон об охране здоровья. Раньше я думал, что сроки беременности может установить женщина по последним месячным, или, в крайнем случае, может определить врач. Это я так думал, идиотом был. Да-да, у меня есть сертификат, я был гинекологом. Ни фига подобного, в законе, в одной статье, по-моему, 53-я статья, четко записано, что сроки беременности определяются уполномоченным федеральным органом исполнительной власти.

Статья 53.

«Медицинские критерии рождения, в том числе сроки беременности, масса тела ребенка при рождении и признаки живорождения, а также порядок выдачи документа о рождении и его форма утверждаются уполномоченным федеральным органом исполнительной власти».

[Федеральный закон Ф3-323]

Комаров: - Но это смешно, а есть и грустный момент. В 90-е годы я был руководителем группы разработчиков законодательства об охране здоровья граждан. Это был демократический закон, потому что в центре внимания был пациент и его проблемы. Человек был в центре внимания. В 2012 г. Минздрав решил все изменить, и они создали новый, 323-й закон, и там что записано? Раньше у нас было так: изъять органы у умершего можно было только при согласовании с родственниками. Сейчас все сделали иначе, добавили «не»: нельзя изымать органы при несогласии родственников. А родственники и не знают, что они должны в письменном виде написать отказ. И уже во многих местах 
возвращают мешок с костями. В общем, я вам должен сказать, что это просто ужас, что творится у нас в здравоохранении.

Статья 47.

«Изъятие органов и тканей для трансплантации (пересадки) у трупа не допускается, если медицинская организация на момент изъятия в установленном законодательством Российской Федерации порядке поставлена в известность о том, что данное лицо при жизни либо иные лица в случаях, указанных в частях 7 и 8 настоящей статьи, заявили о своем несогласии на изъятие его органов и тканей после смерти для трансплантации (пересадки)».

[Федеральный закон Ф3-323].

Немщуов: - Вы хотите сказать, что все это можно быстро перестроить?

Комаров: - Быстро не получится, но я могу сказать, что нужно сделать. Во-первых, мы должны отказаться от рынка в здравоохранении, это нерыночная система, прибыли здесь не должно быть, т.е. не должно быть бизнеса на болезнях. Перед лицом болезни или смерти все равны: богатые, бедные, все. Поэтому надо отказаться от рыночной системы страхования. Страховые компании, которые у нас созданы, - частные и коммерческие, пусть они занимаются добровольным или частным страхованием, пожалуйста, сколько хотите. Фонды переходят в органы управления в виде отделов по финансированию, но это не возврат к старой системе. Не дай Бог! Возвращаться к старой системе нельзя, она была мобилизационной, централизованной, там критерии были идиотские, оплата шла за койкодни, за количество посещений, по смете. Сейчас должно быть все иначе, должны быть договорные отношения между органами здравоохранения и медицинскими учреждениями, где в договорах должны быть прописаны объемы помощи, уровень помощи, качество и результаты. А сейчас результаты никого не волнуют. И очень легко сейчас бесплатную помощь перевести в платную.

Андреев: - Юрий Михайлович, можно два вопроса. Вопрос первый, согласны ли вы с тем, что у нас нет системы медицинского страхования?

Комаров: - Согласен. Это не страхование. У нас его и не может быть - из-за территориальных и других особенностей. Сейчас самая лучшая система страхования не в Германии, а в Нидерландах. Они над ней работают уже 15 лет со времен реформы Деккера. И сказали, что еще нужно 25 лет.

В чем смысл страхования у них? Есть три уровня: первый - на самом верху пациент, ради которого все это делается, в серединке - страховые компании, внизу - медучреждения. С чего начинается? Страховые компании заключают на основе тендера, т.е. на конкурсной основе, договоры с медицинскими учреждениями на оказание определенных услуг. С одним учреждением - на кардиологические услуги, с другим - на онкологические и так далее. Соотношение цена-качество играет роль. Таким образом они формируют набор услуг и затем выставляют его на рынок для пациентов. Пациенты же выбирают не учреждение, не врача, а ту страховую компанию, которая уже заключила или имеет намерение заключить договоры с определенными учреждениями, с определенными врачами и так 
далее. А затем, когда пациенты согласились с этим, они выходят на органы финансирования. Вот примерно так строится современная система страхования. Основа конкуренция.

Второе. В основе страхования лежит все-таки конкуренция медицинских учреждений и прибыль. Вот скажем американская система, там, если больного кто-то вылечит, так все врачи на него окрысятся, скажут, как, а я, почему я его не лечил, почему ты ко мне его не направил? Потому что страховка - это деньги, а не пациенты. Это деньги национальной страховой организации. Я был во многих странах, я проехал весь мир, видел эти системы страхования везде, жил в семьях врачей, в Голландии, например, вел с ними переговоры.

Андреев: - Голландцы же были очень недовольны своей страховой системой еще лет 10 назад.

Комаров: - Да, но вот реформа Деккера, которую они сейчас осуществляют, как раз и направлена на то, чтобы снять это недовольство.

Андреев: - А второй вопрос вот какой: я высоко ценю всякие изобретения. То, что вы придумали, все это хорошо. Но я человек очень серый, я всегда считаю, что надо взять образец и его скопировать. Поэтому я против того, чтобы всегда что-то изобретать.

Комаров: - Нет-нет, это же не изобретение, это взяты лучшие образцы.

Андреев: - Нет, взять один готовый образец, взять, например, эстонские реформы.

Иванова: - И внедрить их в Псковской области. Вы же не предлагаете эстонский проект перенести на Россию?

Комаров: - Я могу рассказать, в чем минусы эстонского образца. Там система страхования. Они построили в Таллинне одну колоссальную современную больницу скорой помощи одну на все республику. Как она работает? Принцип такой: первый этаж отводится для неотложных больных, там операционные общего типа, специализированные, там реанимация, там интенсивная терапия, там работают стажеры, еще не врачи, которые не имеют лицензии на врачебную деятельность, и там даже койки передвижные. Самой скорой помощи, как таковой, нет; на скорой помощи работают парамедики. Они окончили двухнедельные курсы, где учат навыкам, они ничего не понимают ни в медицине, ни в человеке, хотя знают, как поставить иглу, как сделать укол, как поставить систему. Это они умеют, этому их учат. Их главная задача - как можно быстрее довезти больного до этой больницы. Так работает, в основном, весь мир: как можно скорее тяжелого больного довезти до медицинской помощи.

У нас была другая система здравоохранения, мы таких больниц не строили. Мы, по постановлению ЦК КПСС и Совета Министров, строили тысячекоечники в каждой области, но эти тысячекоечники не предназначены для массового поступления больных. Приемное отделение для этого не приспособлено. Никак. Поэтому сейчас у нас акцент делается на оказании помощи именно врачом скорой помощи, акцент делается на этом. У нас есть такой человек в Питере, Сергей Багненко, сейчас он ректор медицинского университета имени академика И.П. Павлова. Я с ним знаком, посмотрел его работы, вы знаете, он хороший 
хирург, хорошо оперирует на печени по неотложным состояниям. Но его сделали главным специалистом по скорой помощи, а это совсем другое, это другая сфера деятельности. И он говорит, как и вы: почему бы не взять готовый образец, давайте скопируем Эстонию, Штаты. Он съездил туда, посмотрел, как это работает, давайте, говорит, посадим на скорую помощь парамедиков, зачем нам нужны дорогостоящие врачи на скорую помощь, зачем нам водители нужны? Ну, парамедиков у нас нет, посадим фельдшеров. Один фельдшер чтобы рулил, а второй помогал носить пациентов. Я полез специально в Интернет, у меня база Росздравнадзора, посмотрел, кто у нас фельдшера. Оказывается, 85\% наших фельдшеров - женщины, причем в возрасте 35 лет и старше. Я подумал: как эти тетки будут носиться по этажам? Это просто издевательство над людьми. Это первое.

Во-вторых, у нас главная задача - противоположная. У нас врач скорой помощи должен быть наиболее квалифицированным. Багненко считает, что все равно за такой короткий промежуток времени врач не поставит диагноз, но это и не входит в задачи врача скорой помощи - ставить диагноз. В его задачу входит снять проблему пациента в данный момент и решить его судьбу на месте. Так у нас сложилось, и нельзя чужой опыт просто пересадить на нашу почву, которая уж сформирована.

Немйов: - А как же вы новую систему здравоохранения предлагаете, когда для этого почвы нет?

Комаров: - Я предлагаю переформатировать эту систему.

Школьников: - Юрий Михайлович, с одной стороны, все понятно, я уверен, что вы правы. Но, с другой стороны, я, как и Евгений Михайлович, тоже верю в образцы, просто из практически соображений. Если есть образец, то можно посмотреть, как практические проблемы решаются в образцовой стране, можно найти инструкторов, тех, кто поделится конкретным опытом. Можно поехать и посмотреть все на месте.

Комаров: - А что у нас тупее люди?

Школьников: - Дело не в тупости, дело в том, чтобы иметь положительный пример во всех деталях перед глазами.

Комаров: - У нас есть команда, которая стоит всех вместе взятых западников. Это примерно 10 человек, которые прекрасно в этом деле соображают.

Андреев: - На мой взгляд, образец - это гораздо убедительнее.

Комаров: - Нет, там только деньги делаются.

Вишневский: - Мы должны двигаться к завершению нашего Круглого стола. Мы, конечно, не решили и не решим всех поднятых сегодня вопросов. Хорошо это или плохо, но Россия - не Эстония. По сравнению с эстонскими, наши проблемы кажутся неподъемными. Хотя, как я понял, кое у кого все-таки есть оптимизм по поводу возможностей нашей системы здравоохранения, вера в то, что она может что-то сделать.

Комаров: - Она не может, сначала с ней нужно что-то сделать.

Вишневский: - Напомню, с чего мы начали, - с огромного отставания России в деле 
снижения смертности от множества стран, не всегда даже самых развитых и богатых. Мне кажется, что среди всех наших запущенных вопросов - это самый запущенный. Пока это отставание не будет преодолено, мы будем по-прежнему преждевременно терять миллионы жизней, очень часто - людей в цветущих возрастах, особенно мужчин, смертность которых особенно высока. Странно, что это никем не воспринимается как первоочередная проблема национальной безопасности. Можно, конечно, охраняя жизнь наших граждан, наводнить метро полицейскими, заодно оптимизировав число врачей в городских больницах. Но может быть, вначале следует лучше посчитать, где будет больше жизней спасено, а где потеряно?

Я не склонен переоценивать вклад нашего сегодняшнего обсуждения в решение столь сложной проблемы. В лучшем случае, мы могли бы сыграть роль эстонских парамедиков, способных быстро довезти пациента до настоящего специалиста. Но скажите куда везти.

Большое спасибо всем. Я надеюсь на дальнейшее сотрудничество.

\section{ЛИТЕРАТУРА}

Вишневский А. (1986). Человеческий фактор в демографическом измерении // Коммунист. №17: 71-72.

Население России 2012: двадцатый ежегодный демографический доклад (2014) / Отв. ред. А.Г. Вишневский. М.: Издательский дом НИУ ВШЭ.

Онищенко Г. (2009). Выйти из алкогольно-табачного тумана // Российская газета. 14 января 2009 г.

Основные положения стратегии охраны здоровья населения РФ на период 2013-2020гг. URL: https://komitetgi.ru/projects/1360

Постановление Правительства РФ №1049 от 21 ноября 2013 г. «Об утверждении Правил представления органами записи актов гражданского состояния сведений о государственной регистрации рождения, смерти, заключения и расторжения брака в Федеральную службу государственной статистики».

Соботка Т., В. Лутц (2011). Коэффициент суммарной рождаемости дает политикам дезориентирующие сигналы: не следует ли отказаться от использования этого показателя (перевод с английского) // Экономический журнал Высшей школы экономики. Том 15. №4: 444-471.

Сталин И.В. (1952). Политический отчет Центрального Комитета на XIV съезде ВКП(б) 18 декабря 1925 года // И.В. Сталин Сочинения. Т. 7. М.: 340.

Федеральный закон Ф3-143 от 15.11 .1997 (ред. от 31.12.2014) «Об актах гражданского состояния».

Федеральный закон ФЗ-323 от 21.11.2011 «Об основах охраны здоровья граждан в Российской Федерации».

Grigoriev P., F. Mesle, V.M. Shkolnikov, E.M. Andreev, A. Fihel, M. Pechholdova, J. Vallin (2014). The recent mortality decline in Russia: beginning of the cardiovascular revolution? // Population and Development Review. 40(1): 107-129. 
Leon D.A., L. Chenet, V.M. Shkolnikov, S.Zakharov, J. Shapiro, G.Rakhmanova, S.Vassin, M. McKee (1997). Huge variations in Russian mortality rates 1984-1994; artefact, alcohol, or what? // The Lancet. 350-9075: 383-388.

McKee M., D.A. Leon (2013). Components and possible determinants of decrease in Russian mortality in 2004-2010 // Demographic Research. 28 (32): 917-950.

McKee M., V. Shkolnikov, D. Leon (2001). Alcohol is implicated in the fluctuations in cardiovascular diseases in Russia since the 1980s // Ann Epidemiol. 11: 1-6.

Preston S.H. (1975). The Changing Relation between Mortality and Level of Economic Development // Population Studies. 29 (2): 231-248.

Terris M. (1976). The Epidemiologic Revolution, National Health Insurance and the Role of Health Departments //American Journal of Public Health. 66 (12): 1156.

Zaridze D., P. Brennan, J. Boreham, A. Boroda, R. Karpov, A. Lazarev, I. Konobeevskaya, V. Igitov, T. Terechova, P. Boffetta, R. Peto (2009). Alcohol and cause-specific mortality in Russia: a retrospective case-control study of 48557 adult deaths // Lancet 373-9682: 22012214.

Zaridze D., S. Lewington, A. Boroda, G. Scélo, R. Karpov, A. Lazarev, I. Konobeevskaya, V. Igitov, T. Terechova (2014). Alcohol and mortality in Russia: prospective observational study of 151000 adults // The Lancet. 383-9927: 1465 - 1473. 


\title{
HOW TO OVERCOME RUSSIA'S LAG IN LIFE EXPECTANCY?
}

\author{
ROUND TABLE BY THE EDITORIAL OFFICE OF THE "DEMOGRAPHIC REVIEW" \\ TOGETHER WITH THE HSE INSTITUTE OF DEMOGRAPHY
}

\begin{abstract}
The article presents materials of the Round table organized by the editorial office of the "Demographic Review" together with the HSE Institute of Demography. Roundtable participants conclude that there is a significant gap between Russia and most developed countries in life expectancy, and discuss recent trends in mortality and life expectancy in Russia and the question of their regional differences. They consider that the current state of statistical information on mortality and morbidity of the population of Russia should be critically assessed. Sex-specific mortality and changes in the structure of causes of death in Russia since 1990 are discussed, and the link between mortality trends and alcohol consumption is examined. Roundtable participants pay attention to the low efficiency of the Russian health care system and reflect on ways of improving the system, without which it is impossible to overcome the current Russian backwardness.
\end{abstract}

The Round table, held on April 17, 2015, was attended by the leading experts in the field of demography and public health:

Evgeny Andreev, Senior Fellow at the Center of Demographic Research, New Economic School; Anatoly Vishnevsky, Director of the Institute of Demography, National Research University Higher School of Economics;

Sergey Ermakov, Professor, Senior Researcher at the Institute of Social and Economic Studies of Population; Chief Researcher at the Research Institute of Health Organization and Informatics, Ministry of Health of Russia;

Alla Ivanov, Professor, Head of the Department of Population Health Statistics at the Research Institute of Health Organization and Informatics, Ministry of Health of Russia;

Ekaterina Kvasha, Senior Research Fellow, Institute of Demography, National Research University Higher School of Economics;

Yury Komarov, Professor, Member of the Committee of Civil Initiatives;

Tatiana Kharkova, Senior Research Fellow, Institute of Demography, National Research University Higher School of Economics;

Sergey Shishkin, Director of the Health Policy Centre, National Research University Higher School of Economics;

Vladimir Shkolnikov, Head of the Laboratory of Demographic Data at Max Planck Institute of Demographic Research (Germany).

Keywords: life expectancy, mortality, causes of death, health care system, Russia

\section{REFERENCES}

Federal'nyy zakon FZ-143 ot 15.11 .1997 (red. ot 31.12.2014) "Ob aktakh grazhdanskogo sostoyaniya" [Federal Law FZ-143 from 11.15.1997 (ed. Of 31.12.2014) “On Acts of Civil Status"].

Federal'nyy zakon FZ-323 ot 21.11.2011 “Ob osnovakh okhrany zdorov'ya grazhdan v Rossiyskoy Federatsii” [Federal Law FZ-323 from 21.11.2011 "On the basis of public health protection in the Russian Federation."].

Grigoriev P., F. Mesle, V.M. Shkolnikov, E.M. Andreev, A. Fihel, M. Pechholdova, J. Vallin (2014). The recent mortality decline in Russia: beginning of the cardiovascular revolution? // Population and Development Review. 40(1): 107-129.

Leon D.A., L. Chenet, V.M. Shkolnikov, S.Zakharov, J. Shapiro, G.Rakhmanova, S.Vassin, M. McKee (1997). Huge variations in Russian mortality rates 1984-1994; artefact, alcohol, or what? // The Lancet. 350-9075: 383-388. 
McKee M., D.A. Leon (2013). Components and possible determinants of decrease in Russian mortality in 2004-2010 // Demographic Research. 28 (32): 917-950.

McKee M., V. Shkolnikov, D. Leon (2001). Alcohol is implicated in the fluctuations in cardiovascular diseases in Russia since the 1980s // Ann Epidemiol. 11: 1-6.

Naseleniye Rossii 2012: dvadtsatyy yezhegodnyy demograficheskiy doklad [Population of Russia 2012: Twentieth annual demographic report] (2014) / Otv. red. A.G. Vishnevskiy. M.: Izdatel'skiy dom NIU VSHE.

Onishchenko G. (2009). Vyyti iz alkogol'no-tabachnogo tumana [To come out of the alcoholtobacco fog] // Rossiyskaya gazeta. 14 yanvarya $2009 \mathrm{~g}$.

Osnovnyye polozheniya strategii okhrany zdorov'ya naseleniya RF na period 2013-2020gg. [The main issues of the health population strategy in the Russian Federation for the period 20132020] URL: https://komitetgi.ru/projects/1360

Postanovleniye Pravitel'stva RF №1049 ot 21 noyabrya 2013 g. “Ob utverzhdenii pravil predstavleniya organami zapisi aktov grazhdanskogo sostoyaniya svedeniy o gosudarstvennoy registratsii rozhdeniya, smerti, zaklyucheniya i rastorzheniya braka $\mathrm{v}$ Federal'nuyu sluzhbu gosudarstvennoy statistiki” [RF Government Resolution №1049 from November 21, 2013 "On approval of the rules of presenting the data on state registration of births, deaths, marriages and divorces to the Federal Service of State Statistics by the register offices."].

Preston S.H. (1975). The Changing Relation between Mortality and Level of Economic Development // Population Studies. 29 (2): 231-248.

Sobotka T., W. Lutz (2009). Misleading Policy Messages from the Period TFR: Should We Stop Using It? // European Demographic Research Papers 4. Vienna: Vienna Institute of Demography of the Austrian Academy of Sciences.

Stalin I.V. (1952). Politicheskiy otchet Tsentral'nogo Komiteta na XIV s"yezde VKP(b) 18 dekabrya 1925 goda [The political report of the Central Committee at the XIV Congress of the CPSU (b) December 18, 1925] // I.V. Stalin. Sochineniya. T. 7. M.: 340.

Terris M. (1976). The Epidemiologic Revolution, National Health Insurance and the Role of Health Departments //American Journal of Public Health. 66 (12): 1156.

Vishnevsky A. (1986). Chelovecheskiy faktor v demograficheskom izmerenii [The human factor in the demographic dimension] // Kommunist. №17: 71-72. 